\title{
Religious Subcultures and Reading Culture
}

\section{The Case of Heyman Jacobsz's Sondaechs Schoole (1623)}

\author{
Jan van de Kamp \\ Associate Professor in Church History, Vrije Universiteit Amsterdam, \\ Amsterdam, the Netherlands \\ j.vande.kamp@vu.nl
}

\begin{abstract}
For religious subcultures, the reading of religious books was of great importance, even for Roman Catholics, renowned for their ritual-mindedness and the prevailing limitations in terms of religious reading for laypeople. This article aims to reveal the extent to which the status and role of a subculture affected the printing history and reception of religious books. The Post-Reformation Low Countries - split into the South, where the Catholics were a dominant culture, and the Dutch Republic in the North, where they were a subculture - provides an excellent case study. A very popular meditation book serves as the source for the study, namely Sondaechs Schoole (Sunday school) (1623).
\end{abstract}

\section{Keywords}

religious subculture - reading culture - Sunday school - Roman Catholicism - Dutch Republic - Habsburg Netherlands

\section{Introduction}

Religious literature, or devotional literature, was central to the piety of individuals and families in early modern times. ${ }^{1}$ It was used both by followers of

1 Discovering the Riches of the Word. Religious Reading in Late Medieval and Early Modern Europe, ed. S. Corbellini, M. Hoogvliet and B. Ramakers (Leiden etc. 2015). 
Christian confessions that were officially permitted in the area where they lived (dominant cultures) and by religious subcultures, groups with their own, distinct lifestyle, that were not officially accepted. ${ }^{2}$ The latter, who were not permitted to worship publicly, may have read such literature even more intensively. As a substitute for worship, such groups gathered at home or elsewhere in a house to read, pray, and sing. ${ }^{3}$

Examples of this are known from previous research, such as that of Dietmar Weikl, who portrayed 'religious life in secret Protestantism in the Habsburg lands' in the seventeenth and eighteenth centuries. In private houses, theological treatises, prayer books and hymn books were read aloud regularly and passed down from generation to generation. Thus, even those with poor reading skills became acquainted with the contents of these books, which is an indication of their significance. Until the end of the eighteenth century, when Protestants were officially accepted in these countries, the reading of these works was of great importance for the survival of Protestants in these regions. ${ }^{4}$

Scholarship has previously held that this was an exclusively Protestant practice. Roman Catholics were supposed to have only used religious books for ecclesiastical purposes, that is, as communion books, prayer books, etc. ${ }^{5}$ However, recent studies have indicated that early modern Roman Catholics, too, who were known for their ritual-mindedness and for their clergy's discouragement

2 K. Gelder, Subcultures. Cultural Histories and Social Practice (Oxon-New York 2007). Carolina Lenarduzzi has adapted this term to Roman Catholicism in the Republic in the unpublished version of her dissertation, C. Lenarduzzi, 'Katholiek in de Republiek. Subcultuur en tegencultuur in Nederland, 1570-1750' (unpubl. PhD diss. Leiden 2018), pp. 8-12.

3 J. van de Kamp, 'De internationale receptie van The Practice of Piety en de plaats van de Nederlandse vertaling daarin', in: De praktijk der godzaligheid. Studies over De practycke ofte oeffeninghe der godtzaligheydt (1620) van Lewis Bayly, ed. W. J. op 't Hof, A. A. den Hollander and F. W. Huisman (Amstelveen 2009), p. 294; J. van de Kamp, 'Evangelische Spiritualität im 17. Jahrhundert, vor allem im Blick auf den Pietismus', in: Evangelische Spiritualität, vol. 1: Geschichte, ed. P. Zimmerling (Göttingen 2017), p. 309.

4 D. Weikl, 'Das religiöse Leben im Geheimprotestantismus in den habsburgischen Erblanden', in: R. Leeb, M. Scheutz and D. Weikl, Geheimprotestantismus und evangelische Kirchen in der Habsburgermonarchie und im Erzstift Salzburg (17./18.Jahrhundert) (Vienna 2009), pp. 457-73; M. Scheutz, 'Glauben sie übrigens, daß ich den Teifel nicht so schwartz mahlen könne, wie er in sich selbsten ist”. Die habsburgische Zentralverwaltung und die Vielfalt der untergrundprotestantischen Zeichen um die Mitte des 18. Jahrhunderts', in: Konfessionelle Ambiguität: Uneindeutigkeit und Verstellung als religiöse Praxis in der Frühen Neuzeit, ed. A. Pietsch and B. Stollberg-Rillinger (Gütersloh 2013), pp. 357-61.

5 A. G. Dickens, Reformation and Society in Sixteenth-Century Europe (London 1966), p. 51; E. Eisenstein, The Printing Press as an Agent of Change. Communications and Cultural Transformations in Early-Modern Europe (Cambridge 1979), ch. 4. 
of personal reading by laypeople, published 'many books of spirituality' and read religious books as an important part of their family worship. ${ }^{6}$ With regard to England, Alexandra Walsham writes that Counter-Reformation priests, whose very presence was prohibited in the country, employed these works as a replacement for face-to-face catechetical instruction or, in the words of Luis de Granada, as 'domme preachers.' ${ }^{7}$ The lower classes even used these books as relics, believing that they held magical power. ${ }^{8}$

Examples of the religious reading customs of subcultures, such as Protestants in the Habsburg lands and English Catholics, may indicate that subcultures printed and used religious books with a specific purpose. ${ }^{9}$ Reading and passing on a canon of books, using books as a substitute for face-to-face religious instruction, and a magical usage of books may be characteristic of the religious reading of subcultures.

In this article, I will carry out a case study to test this hypothesis by comparing the printing history and reception of a religious book within a subculture and within a dominant culture. The writing concerned was a Catholic work, printed and read both in the North of the Low Countries, where Catholics formed a subculture, and in the South, where they formed the dominant culture. ${ }^{10}$

In order to understand the political, religious, and cultural contexts within which the book was printed and read in the Dutch Catholic subculture, I will first briefly sketch the politico- and cultural-religious dynamics in the Low

6 J. Delumeau, Catholicism between Luther and Voltaire. A New View of the CounterReformation (London 1977), pp. 40-1; M. R. Forster, 'Domestic Devotion and Family Piety in German Catholicism', in: Piety and Family in Early Modern Europe. Essays in Honour of Steven Ozment, ed. M. R. Forster and B. J. Kaplan (Aldershot 2005), pp. 97-114; Books in the Catholic World during the Early Modern Period, ed. N. Maillard Álvarez (Leiden 2014).

7 A. Walsham, "'Domme Preachers"? Post-Reformation English Catholicism and the Culture of Print', Past \& Present, 168 (200o), pp. 72-123. The quote derives from L. de Granada, A Memoriall of a Christian Life, trans. R. Hopkins, (Rouen 1586) p. 12, cited by Walsham, "Domme Preachers"?, p. 8o.

8 A. Walsham, Catholic Reformation in Protestant Britain (London 2016), p. 365.

9 I have published before on the German Reformed minority and its reading of religious literature: J. van de Kamp, 'Filling up the gap? The Use of Lutheran Devotional Literature by German Reformed Protestants in Early Modern Times', in: Luther and Calvinism - Image and Reception of Martin Luther in the History and Theology of Calvinism, ed. H.J. Selderhuis and M. J. Lange van Ravenswaay (Göttingen 2017), pp. 207-20.

10 Cf. on the religious history of Catholics in both areas: Geloven in de Lage Landen. Scharniermomenten in de geschiedenis van het christendom, ed. P. Nissen (Leuven 2004); J. van Eijnatten and F. van Lieburg, Nederlandse religiegeschiedenis (2nd, rev., ed.; Hilversum 2006), pp. 169-343; C. Lenarduzzi, Katholiek in de Republiek. De belevingswereld van een religieuze minderheid 1570-1750 (Nijmegen 2019), pp. 7-49. 
Countries from the late sixteenth century onwards. Although Calvinism had penetrated the Southern Low Countries from around the middle of the sixteenth century, and even though it became influential there, its importance fell definitively in 1585 . After that year, Roman Catholicism was restored in the Southern Low Countries, the territory known as the Habsburg Netherlands, as the only officially sanctioned confession. ${ }^{11}$ However, in the North, that is, the Dutch Republic, Catholicism was not officially allowed until 1795, and its followers had to gather secretly in their schuilkerken (clandestine churches). ${ }^{12}$ A large part of the Dutch Republic, the area north of the Waal river that formed the Utrecht archdiocese of the Catholic church, was considered by Catholicism from 1592 onwards as a mission area under the responsibility of the Dutch Mission (Missio Hollandica). The areas of the Republic that lay south of the river belonged to the Archdiocese of Mechelen (Malines). Somewhat intermediate, both in a geographical respect and regarding their religious situation, were the Generaliteitslanden (Generality Lands) of the Republic, which stood directly under the authority of the States-General. To these lands belonged, among others, Staats-Brabant (Brabant of the States). In the Generality Lands, Catholics were a self-assertive, quantitative majority oriented towards the Habsburg Netherlands. ${ }^{13}$ Moreover, on Sundays they travelled to the Habsburg Netherlands or to the Catholic enclaves within the Dutch Republic, such as the Land van Ravenstein, to attend Catholic worship, a phenomenon known as Auslaufen. ${ }^{14}$

Both in the Dutch Republic and the Habsburg Netherlands, distinct religious identities were formed by religious practices and by political print and plays, and this led to a religio-cultural division between the two territories. ${ }^{15}$ This process was reinforced by the presence of confessional migrants, who had fled either northward or southward, and who took with them their experiences of flight and developed their memories of exile. ${ }^{16}$

\footnotetext{
11 Nissen, op. cit. (n. 10).

12 B. J. Kaplan, 'Fictions of Privacy. House Chapels and the Spatial Accommodation of Religious Dissent in Early Modern Europe', American Historical Review, 107 (2002), pp. 1031-64; Lenarduzzi, op. cit. (n. 10), pp. 36-9.

13 Lenarduzzi, op. cit. (n. 10), pp. 247-92.

14 B. J. Kaplan, Divided by Faith. Religious Conflict and the Practice of Toleration in Early Modern Europe (Cambridge, MA/London 2007), ch. 6.

15 Public Opinion and Changing Identities in the Early Modern Netherlands. Essays in Honour of Alastair Duke, J. Pollmann and A. Spicer (Leiden 2006); J. Pollmann, Catholic Identity and the Revolt of the Netherlands (Oxford 2011).

16 G. H. Janssen, The Dutch Revolt and Catholic Exile in Reformation Europe (Cambridge 2014).
} 
In this contribution, I will use the term 'Northern Netherlands' or 'the North' to denote the present-day territory of the Netherlands, formerly the Dutch Republic and briefly known as the Batavian Republic, but excluding the present-day Dutch provinces of North Brabant and Limburg. Large parts of these provinces were part of the Generality Lands during the Dutch Republic era, and there, the situation of Catholicism differed from that in the other Dutch provinces. I will employ the term 'Southern Netherlands' or 'the South' to signify both the area of present-day Belgium, the former Habsburg Netherlands, and the aforementioned Generality Lands.

In this article, I describe Roman Catholicism in the Republic as a subculture, as Carolina Lenarduzzi did in the unpublished version of her dissertation. ${ }^{17}$ This term seems to account more properly for the distinctive lifestyle that the Catholics fashioned in shaping their own identity than does the often-used notion of 'minority'. ${ }^{18}$ With regard to the concept of a minority, this itself seems problematic, given that Catholics remained a majority for a long time after the introduction of the Reformed faith in the Dutch provinces and that from the second half of the seventeenth century onwards the Catholics received more leeway from the authorities, as well as from the Reformed Church. ${ }^{19}$

The issue of how the identity of Dutch Catholicism was created and shaped has been the object of ongoing research, building further on the work of scholars, including Alexandra Walsham, who studied English Catholicism and who demonstrated the dynamic character of its identity as well as its lay involvement in it. ${ }^{20}$ Dutch Catholic identity, in turn, was created, as researchers such as Charles H. Parker, Judith Pollmann, Jo Spaans, and Geert H. Janssen have shown, not from above, nor from below, but 'from the middle'; that is, it resulted from cooperation between clergy and laypeople, who had agency

17 Lenarduzzi, op. cit. (n.2), pp. 8-12. In the published version, she has shifted towards the concept of minority: Lenarduzzi, op. cit. (n.10), title page, pp. 10-11.

18 C. Kooi, 'Sub Jugo Haereticorum. Minority Catholicism in Early Modern Europe', in: Early Modern Catholicism. Essays in Honour of John W. O'Malley, S. J., ed. K. M. Comerford and H. M. Pabel (Toronto etc. 2001), pp. 147-62; W. Frijhoff, 'Shifting Identities in Hostile Settings. Towards a Comparison of the Catholic Communities in Early Modern Britain and the Northern Netherlands', in: Catholic Communities in Protestant States: Britain and the Netherlands c.1570-1720, ed. B. Kaplan et al. (Manchester/New York 2009), pp. 2-3.

19 W. Frijhoff and M. Spies, 1650 . Bevochten eendracht (2nd ed., The Hague 2000), pp. 354-5.; H. Knippenberg, De religieuze kaart van Nederland. Omvang en geografische spreiding van de godsdienstige gezindten vanaf de Reformatie tot heden (Assen/Maastricht 1992), p. 23f; Lenarduzzi, op. cit. (n.10), pp. 29-31, p. 346.

20 A. Walsham, Church Papists. Catholicism, Conformity and Confessional Polemic in Early Modern England (London 1993); Walsham., op. cit. (n.8). 
themselves. ${ }^{21}$ The process of identity-formation among Dutch Catholics resulted not in a homogenous but in a multi-layered identity. Within a Catholic individual, the balance between civic, professional, familial, national and religious identities could shift, as Bertrand Forclaz, Jaap Geraerts and Lenarduzzi have shown. ${ }^{22}$

As mentioned above, in order to address my research question of whether religious subcultures had a distinct printing history and reception of religious books, I will comparatively study these aspects for a Catholic work that was printed and read in both the Dutch Republic and the Habsburg Netherlands. To qualify as the object of this research, such a book ought to have gone through many editions, to enable the tracing of certain patterns. An excellent example of such a writing exists, namely, a popular yet understudied book consisting of Bible passages, together with explanations: Sondaechs Schoole (Sunday School) (1623). The work was written by Heyman Jacobsz, probably a schoolmaster in the Dutch Republic: thus, a layman. He published, among other works, a short manual for writing letters and other documents: Ghemeene seyndt-brieven (General letters) (1597). In many editions, Sondaechs Schoole was combined with a similar work for use on church holidays, namely, Heylighedaechs Schoole (Holy Day School) (1621) by Joannes Fonck, as a 'pair-book'. In this contribution, I will focus on Sondaechs Schoole, which was published 57 times until 1892. Jacobsz mentions characteristically Catholic ideas in passing, but on the whole, he writes in a general Christian manner. ${ }^{23}$ Pontianus Polman dedicated an essay to the book in 1965. Moreover, it is discussed in an article of 2006 by Theo Clemens on religious reading culture among Dutch Catholics. The contributions by Polman and Clemens only offer an outline; I will investigate Sondaechs Schoole in more detail. ${ }^{24}$

21 C. H. Parker, Faith on the Margins. Catholics and Catholicism in the Dutch Golden Age (Cambridge, MA 20o8); Pollmann, op. cit. (n.15); J. Spaans, De Levens der Maechden. Het verhaal van een religieuze vrouwengemeenschap in de eerste helft van de zeventiende eeuw (Hilversum 2012); Janssen, op. cit. (n.16).

22 B. Forclaz, Catholiques au défi de la Réforme. La coexistence confessionnelle à Utrecht au XVII e siècle (Paris 2014), 143-77, pp. 229-359; J. Geraerts, Patrons of the Old Faith. The Catholic Nobility in Utrecht and Guelders, c.1580-1702 (Leiden 2018), 29-128; Lenarduzzi, op. cit. (n.10).

23 See the list in O. F. M. Polman., 'Heyman Jacobsz. en zijn "Sondaechs-schole", Archief voor de Geschiedenis van de Katholieke Kerk in Nederland, 7 (1965), pp. 162-9o, pp. 188-9o. The oldest edition that has been preserved dates from 1623, but there seems to have been earlier editions, as the title page states that it is a revised version: 'Oversien, verbetert/ende vermeerdert'. For an overview of the editions, see the table in the appendix.

24 Polman, art. cit. (n.23), p. 162; T. Clemens, 'De religieuze leescultuur onder Nederlandse katholieken, 1580-1850: een zoektocht naar wat niet bestaat', in: Tijdschrift voor Nederlandse kerkgeschiedenis, 9 (2006), pp. 54-61. 
One of the propositions of earlier research that I will review in this article is one by Clemens, who stated that the editions of Sondaechs Schoole printed in the Dutch Republic were indicative of a 'strongly traditional religiosity' within Dutch Catholicism in comparison with the editions that were published outside of the book's original area of printing, namely, the province of Holland. ${ }^{25}$ Yet, labelling the religiosity of Dutch Catholics in general as 'strongly traditional' seems to be questionable, as recent research by Judith Pollmann has revealed that, although early modern Catholics all agreed that they had the 'oldest rights' and that oldest was best, nevertheless, 'the religious and devotional predilections into which this conviction translated differed from person to person': that is, from conservative through activist to voluntary adherent. ${ }^{26}$

The title of the work refers to the catechism lessons for children given on Sunday afternoons which were prescribed by the Council of Trent and institutionalised in Catholic countries, including the Habsburg Netherlands. Incidentally, there is an ecclesiastical imprimatur at the end of the book. ${ }^{27}$ Given its title, the book is presented as a written substitute for this type of school. ${ }^{28}$ This indicates that the book was used at school, and, in fact, the title of the edition of 1623, published by Christoffel Fabri at Amsterdam, ${ }^{29}$ states that the writing is an explanation of the epistles which are read in church throughout the year and which may be memorised or translated by children into French, Latin or any other language. ${ }^{30}$ Furthermore, these kinds of 'epistle

25 'een sterk traditionele godsdienstigheid', Clemens, art. cit. (n. 24), p. 59.

26 J. Pollmann, 'Being a Catholic in Early Modern Europe', in: The Ashgate Research Companion to the Counter-Reformation, ed. A. Bamji, G. H. Janssen and M. Laven (Farnham 2013), pp. 165-82, pp. 179-8o.

27 [H. Jacobsz], Sondaechs Schole, ofte uytlegginge op de euangelien van de sondaghen (Leuven [= Amsterdam], Christoffel Fabri [= Cornelis Dircksz Cool] [1646]), p. 382: 'Pueris $\&$ rudioribus utiliter imprimitur $[$ sic $]$. | S.S.O.'

28 Polman, art. cit. (n.23), p. 163.

29 The title page falsely states that the edition was published at Leuven ('Tot Loven by Christoffel Fabri'). For Dutch Catholic Book Trade in Amsterdam in general, see E. Watson, 'Networks of Devotion. Auction Catalogues and the Catholic Book Trade in Amsterdam, 1650-1700', in: Book Trade Catalogues in Early Modern Europe, ed. G. Kemp, A. Pettegree and A. der Weduwen (Leiden/Boston 2021).

30 'Sondaechs-Schole, Inhoudende corte uytlegginge op de Euangelien van de Sondaghen/ also men die hout in de heylighe Kercke door het gantsche Jaer/ bequaem zijnde om de kinderen te laten leeren ofte vertalen in Francoys oft Latijn/ of in eenighe ander sprake.' On religious reading among youth in the Northern and Southern Netherlands, see: A. den Hollander, 'Bijbelse lees- en leerstof', in: De Bijbel in de Lage Landen. Elf eeuwen van vertalen, ed. P. Gillaerts et al. (Heerenveen 2015), pp. 466-7.; H. Meeus, “What's Learnt in the Cradle Lasts till the Tomb." Counter-Reformation Strategies in the Southern Low 
books', which consisted of the Gospel lessons for each Sunday, had been used at schools in the northern parts of the Netherlands since the Late Middle Ages. ${ }^{31} \mathrm{~A}$ further indication for the use of the book at school are the poems for children, as well as for parents and schoolmasters, that are included in many editions. ${ }^{32}$

However, the intended audience seems to have widened because the edition of 1646 offered an added preface in which the target audience is extended to uneducated persons: sailors, travellers to foreign and desolate countries, those who are hungry for the Word of God and want to 'ruminate' on it constantly, and those who cannot attend service due to illness or other reasons. ${ }^{33}$ To demonstrate the profitableness of the book, the preface writer - evidently the publisher - tells a miraculous story to improve people's lives: it was revealed to someone who was sailing across the Dutch Zuiderzee and who was in peril of drowning 'that he could get this book at our house'. Having escaped from death and having bought the booklet, he was converted from a very godless to a very virtuous and sincere life. ${ }^{34}$

In order to find out whether the book culture and reading culture of the Catholic subculture in the North differed from the dominant culture in the South, I will firstly examine the developments in the subsequent editions and, secondly, the reception of the booklet under consideration:

1 The question of who published or printed it, what materials it is made of, what its contents were, and how its structure and content developed over time. In order to answer these questions, I will analyse texts and title pages from the text, and the adaptations of these materials in the various editions.

2 Who used it, in what context and in what manner? For these questions, I will investigate provenances, i.e., the traces of book owners.

Countries to Entice the Youth into Religious Reading', in: Corbellini et al., op. cit. (n. 1), pp. 339-66. The edition of 1817 by the widow Bontamps of Venlo states on its title page that it is appropriate both for the elderly and for the education of children: 'zeer bekwaam voor bejaarde menschen en om de kinderen te laten leeren'.

31 P. Th. F. M. Boekholt and E. P. de Booy, Geschiedenis van de school in Nederland vanaf de middeleeuwen tot aan de huidige tijd (Assen/Maastricht 1987), p. 34.

32 Poem for parents: 1623 edition, [A4v]; poem for schoolchildren: 1675 edition Fabri/Cool, $\left[{ }^{*} 6 \mathrm{r}\right]-\left[{ }^{*} 7 \mathrm{r}\right]$; poem for parents and schoolmasters: 1675 edition Fabri/Cool, $382-[1]$. See also the table in the appendix. On the practice of including moralizing proverbs and poems: Boekholt and de Booy, op. cit. (n. 31), pp. 36-7.

33 [Jacobsz], op. cit. (n. 27 ), * $4 \mathrm{v}^{-*}{ }^{*}{ }^{\mathrm{v}}$.

34 [Jacobsz], op. cit. (n. 27), ${ }^{*} \mathrm{r}-\mathrm{v}$. The quote 'dat hy dit Boekjen tot onsen huyse soude bekomen' at ${ }^{*} \mathrm{r}$. 
My approach to the subject is thus of a book-historical and cultural-historical nature. ${ }^{35}$ For this investigation, I have consulted copies of editions available in libraries in Antwerp, Leuven, and Utrecht, which together comprise about 8 o per cent of all known editions (see the table in the appendix).

In addition to the publication history and the reception of Sondaechs Schoole, the manner in which it was distributed is interesting, too, given the more or less 'undercover' nature that it may have had in parts of the Northern Netherlands. ${ }^{36}$ However, due to the lack of data at present, the distribution of the book cannot be addressed here.

\section{The Story of the Editions of Sondaechs Schoole}

First, we shall consider the most obvious characteristics of the editions consecutively. During the seventeenth century, five editions of Sondaechs Schoole appeared, which were published by the Amsterdam publishers Cornelis Dircksz Cool, his son Cornelis, and Michiel de Groot, as well as the Haarlem publisher Niclaes Braau, although Leuven was mentioned as the place of publication on the title pages. ${ }^{37}$ The probable reason for this was not that publishers were in danger of being persecuted for printing Catholic books because Roman Catholic publishers were generally left alone in Amsterdam. On the contrary, Leuven's better reputation in relation to printed books seems to have been the consideration here. ${ }^{38}$

During the eighteenth century, 29 editions of the work appeared. The title pages often state Antwerp as the place of publication, even when a publisher

35 Le livre religieux et ses pratiques / Der Umgang mit dem religiösen Buch. Etudes sur l'histoire du livre religieux en Allemagne et en France à l'epoque moderne / Studien zur Geschichte des religiösen Buches in Deutschland und Frankreich in der Frühen Neuzeit, ed. G. C. Bödeker, G. Chaix and P. Veit (Göttingen 1991).

$36 \quad C f$.the situation in England: E. Havens and E. Patton, 'Underground Networks, Prisons and the Circulation of Counter-Reformation Books in Elizabethan England,' in: Early modern English Catholicism. Identity, Memory and Counter-Reformation, ed. J. E. Kelly and S. Royal (Leiden 2017), pp. 165-188.

37 For short biographical data on these printers and publishers, see the bibliographical databases Short Title Catalogue Netherlands (http://picarta.pica.nl/xslt/DB=3.11/) and Short Title Catalogue Flanders (https://anet.be/submit.phtml?UDses=98225433\%3A359911\&U Dstate $=1 \&$ UDmode $=\&$ UDaccess $=\&$ UDrou $=\% 25$ Start:bopwexe $\&$ UDopac $=$ stcvopac \&UDe xtra=), last accessed 21 June 2021.

38 V. A. de la Montagne, 'Naschrift', Tijdschrift voor Boek- \& Bibliotheekwezen, 3 (1905), pp. 197-200, p. 197 . 
from Amsterdam was actually responsible (Cornelis Stichter II, Gerardus van Bloemen, the heirs of widow Cornelis Stichter II, and Fredericus Johannes van Tetroode) or one from 's-Hertogenbosch (Jacobus Scheffers). Nine editions were actually published in Antwerp, namely, by Petrus Scheffers, the van Soest brothers (Franciscus, Henricus and Joannes Henricus), Theodorus Crajenschot, Petrus Joannes Parys, and Franciscus Ignatius Vinck. Finally, there was a publisher from Venlo and Geldern, namely, Bontamps.

The latter played an important role in the printing of Sondaechs Schoole during the nineteenth century. Of the nineteen editions published, Bontamps produced eleven. In addition to Venlo, the editions were printed in Antwerp, Turnhout, Amsterdam, and 's-Hertogenbosch. It should be mentioned that 's-Hertogenbosch and Venlo belonged to the Generality Lands; Geldern had belonged to the Habsburg Netherlands, but from 1713 onwards appertained to Prussia.

Examining the title pages of the editions published until the nineteenth century, one can observe a high degree of continuity, at least for the prints made in the Northern Netherlands. The title is printed in both Roman typeface and blackletter. Around it is a woodcut in the form of a frame with the Four Evangelists in the four corners, the Apostles Peter and Paul stand in the centre left and right, and at the very bottom appears a lamb with a flag. This cut has several variants: either with the abbreviation JHWH or IHS in the top middle, and with the bottom of the frame either connected to the upper side or not, and with a couple of other differences. ${ }^{39}$ One variant of the title page, dating from c. 1646 (see Fig. 1), Figure 1 continues to be used until the edition published by the heirs of Cornelis Stichter's widow in 1791; there were variations, however: for example, the use of colour (black, or red/black) in the title or illustrations and the additional motifs of a cross or crown.

In the editions from the Generality Lands and the Habsburg Netherlands, there were significant deviations in the title page and structure. Initially, some editions include a list of the moveable church feasts (a permanent almanac), as well as a list of fixed church feasts in the archdiocese of Mechelen (Antwerp 1715, Petrus Scheffers (see Fig. 2) Figure 2; Antwerp 1748, Franciscus van Soest; Antwerp = 's-Hertogenbosch 1751, Jacobus Scheffers; Antwerp 1761, Henricus van Soest; Antwerp [1766], Joannes Henricus van Soest; Antwerp 1774, Petrus

39 Different illustrations of the Evangelists and Apostles are used, and the order of the Evangelists Matthew and John differ. $C f$. the woodcut of the first edition (1623): F. W. H. Hollstein, The Muller Dynastie (Rotterdam 1999), p. 309, who states that the composition is similar to the title page of Evangelien ende epistelen from c. 1585 (ibid. no. 54.1). 


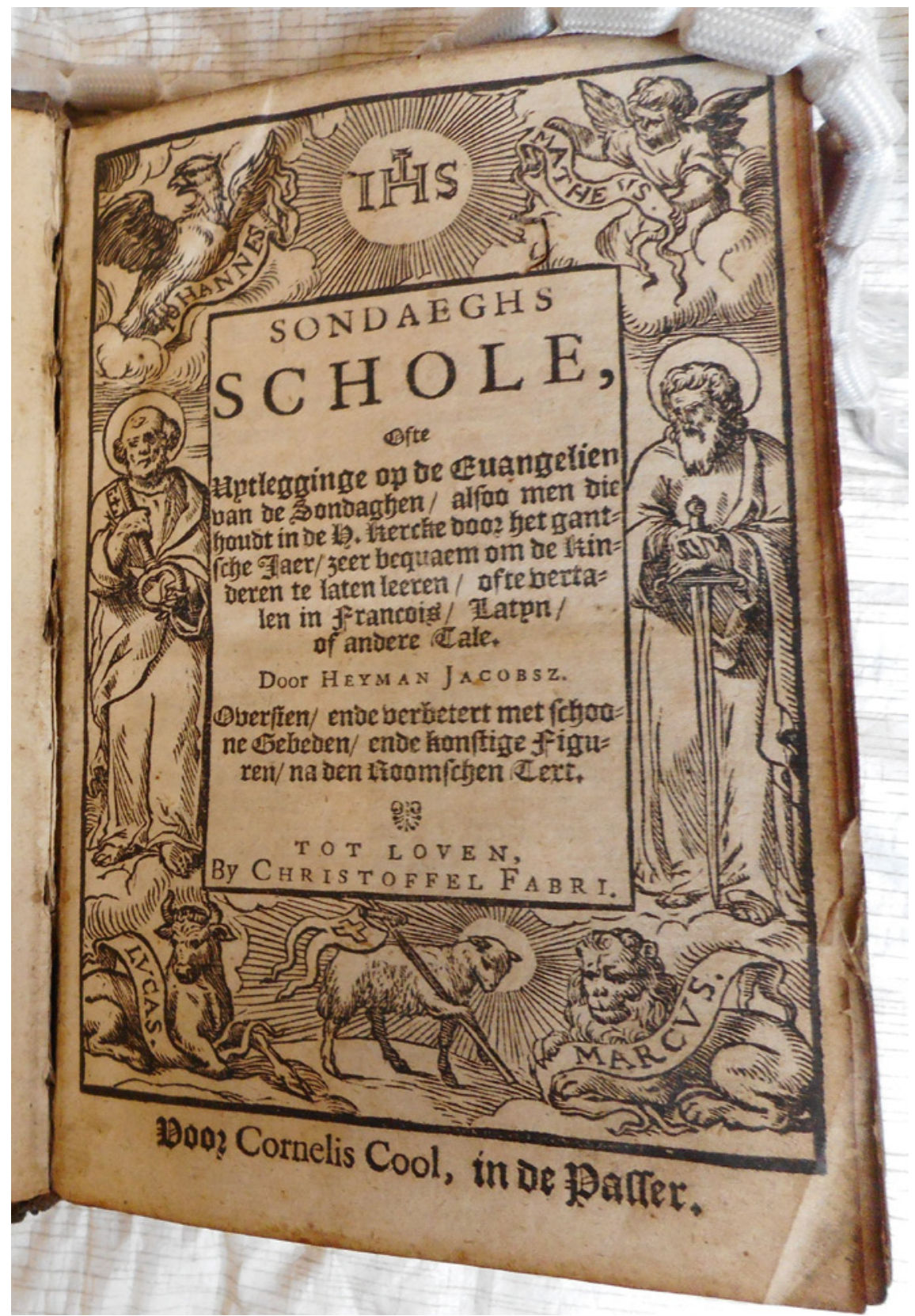

FIGURE 1 The variant of the title page which was used until the Stichter edition of 1791; here, in the edition of 1675 LIBRARY OF THE RUUSBROEC INSTITUTE, ANTWERP, RG 3004 H1 


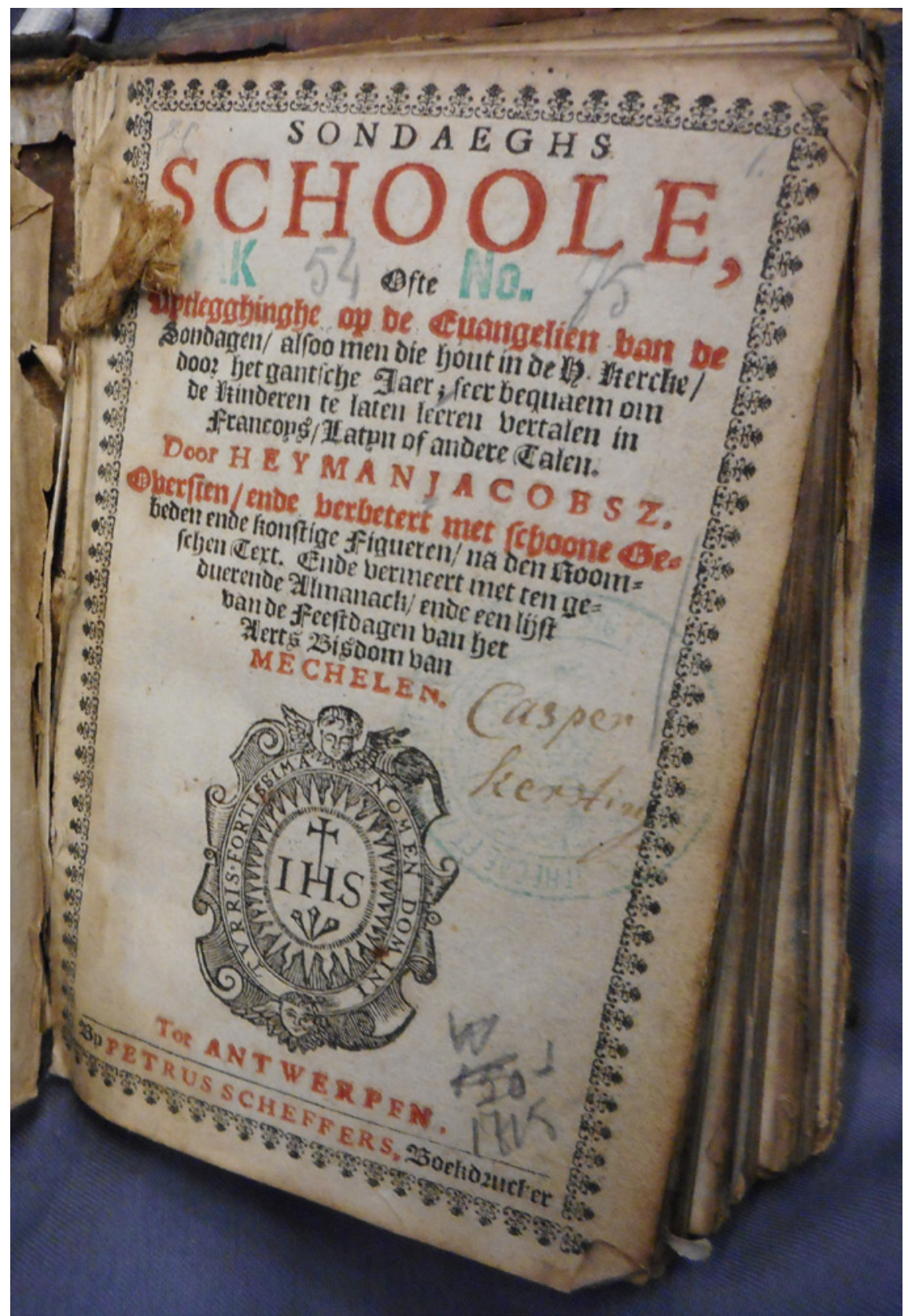

FIGURE 2 The first edition to include a list of the church feasts of the Archdiocese of Mechelen and without a woodcut: published by Petrus Scheffers at Antwerp in 1715 UTRECHT UNIVERSITY LIBRARY, WRT 54/75 
Joannes Parys; Antwerp 1778, Franciscus_Ignatius Vinck; Antwerp c. 1799-1813, Joannes Norbertus Vinck; Antwerp [= Leiden] 17xx, widow Frans de Does). ${ }^{40}$ Furthermore, the editions published by Petrus Scheffers of Antwerp (1715), Jacobus Scheffers of 's-Hertogenbosch (1764), Parys of Antwerp (1774), and finally Franciscus Ignatius Vinck of Antwerp (1778) did not contain a woodcut on the title page. These editions had many more changes relative to the orthography and textual layout on the title page, the illustrations on the title page and in the primary text, as well as the poems, prayers, and instructions for the sanctification of Sunday and daily life placed before and after the primary text. For example, the letter on the title page of the 1778 edition (see Fig. 3) Figure 3 was entirely changed to roman type.

These changes were permanently adopted only belatedly by the publishers in the North, namely, from 1828 onwards (see Fig. 4) Figure $4 .{ }^{41}$ Incidentally, this does not necessarily exclude the possibility that there had been changes in the woodcut on the title page, or in the illustrations elsewhere in the book, in the northern editions prior to that. ${ }^{42}$ In fact, as we have seen, such alterations did occur; however, they did not go as far as in the editions from the South.

In the nineteenth century, these modernizations also appeared in the northern editions, as we have determined from the example of the changed title page of the edition of 1828 . For obvious reasons, the tables of church feasts in the archdiocese of Mechelen were not adopted. In 1820/1821 (see Fig. 5), Figure 5 a completely revised Sondaechs Schoole was even published, the product of Lambertus Engbers, priest and pastor at Vasse, near the town of Almelo. The blackletter is here replaced with roman type, and the meditations written afresh. On the other hand, the title page is similar to the traditional one, being composed with a woodcut that only contains other individual illustrations. In addition, the title explicitly states that the book is intended for domestic devotion, namely for Roman Catholics ${ }^{43}$ - an indication of the growing

40 The list of church holidays to be observed in the diocese of Utrecht may have been the model: Joannes Fonck, Heylige-daeghs schole: inhoudende schoone uytlegginge op de euangelien van de heylige dagen, soo men die houdt in de heylige kercke door 't gansche jaer [...] Van nieuws oversien, ende verbetert (Loven [= Haarlem], Niclaes Braau, [c. 1675]), p. 236-[3].

41 Already in 17xx, an edition without woodcuts was published by the widow of Frans de Does at Antwerp [= Leiden].

42 For the illustrations within the book, engravings made by Christoffel (II) van Sichem may have been used: Polman, art. cit. (n.23), p. 181.

43 L. Engbers, Zondags-school, tot oefening van huisaandacht voor Roomsch-catholyken: bestaande in zedelijke uitleggingen en bemerkingen op de evangelien van de zon-en geboden feestdagen van het geheele jaar (Rotterdam 1821). 


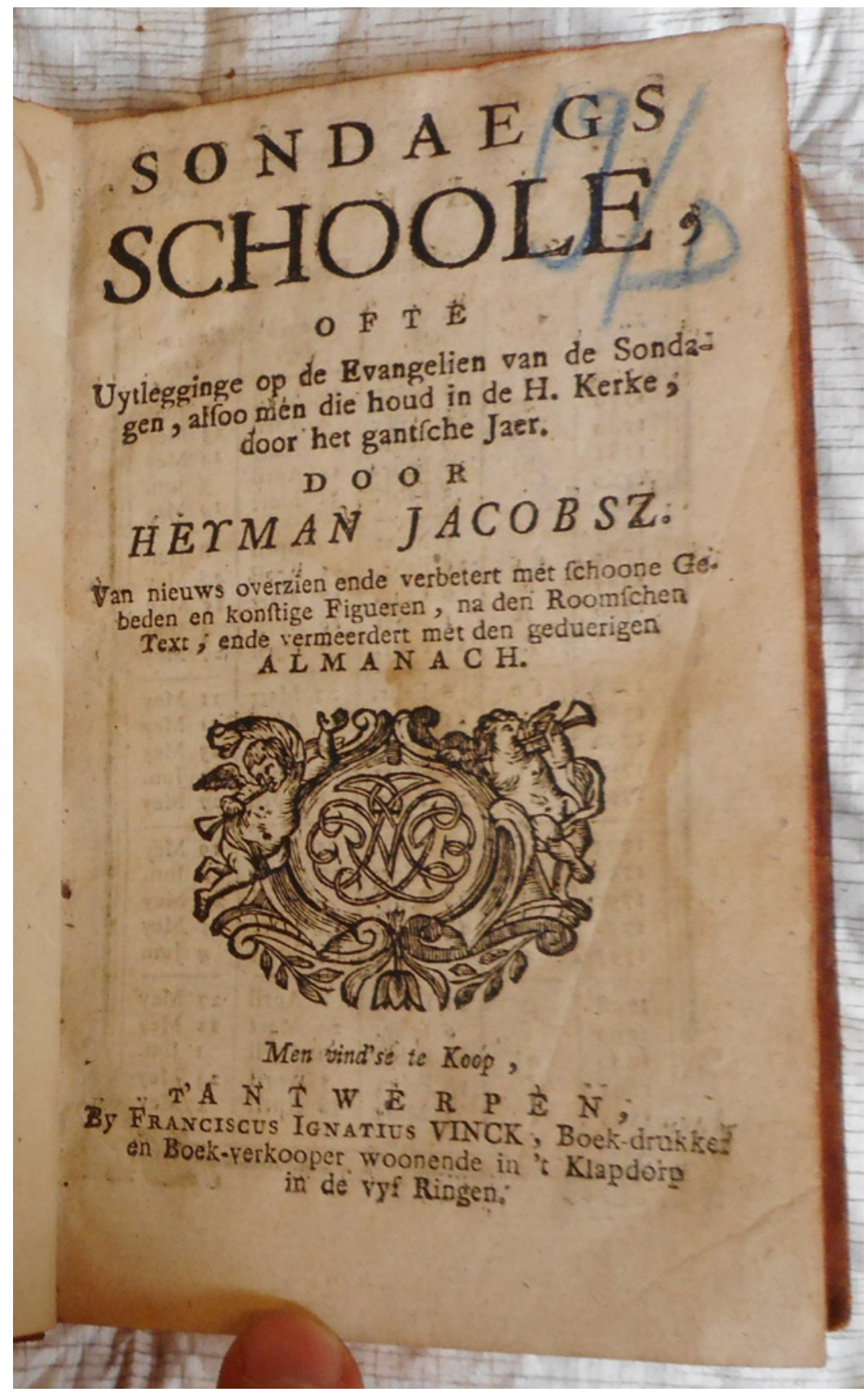

FIGURE 3 The 1778 edition, in which the layout was changed from blackletter to Roman typeface

LIBRARY OF THE RUUSBROEC INSTITUTE, ANTWERP, RG 3004 H 3 


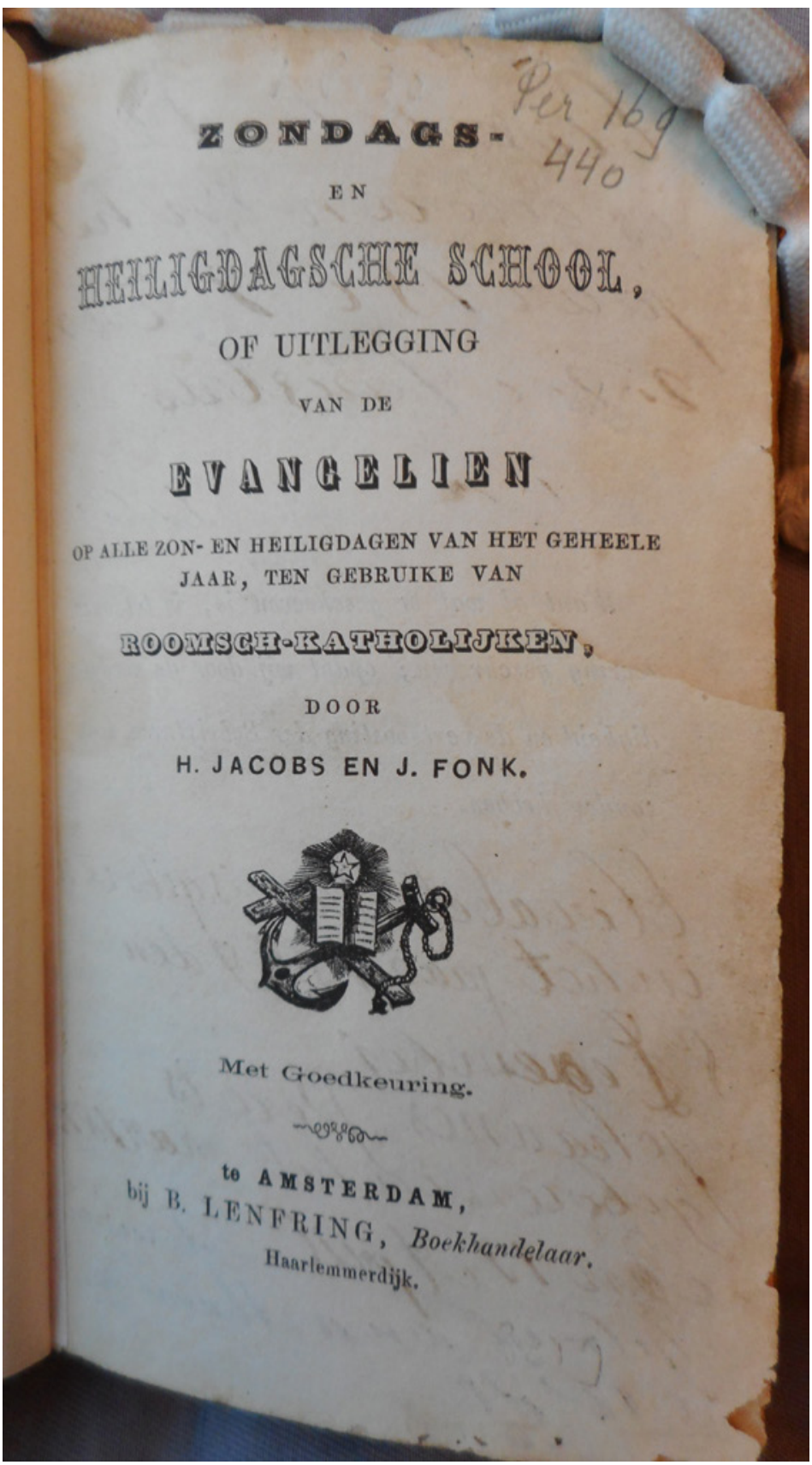

FIGURE 4 First edition in the North adopting the changes already made in the South. This edition was published by B. Lenfring at Amsterdam UTRECHT UNIVERSITY LIBRARY, PER 169-440 


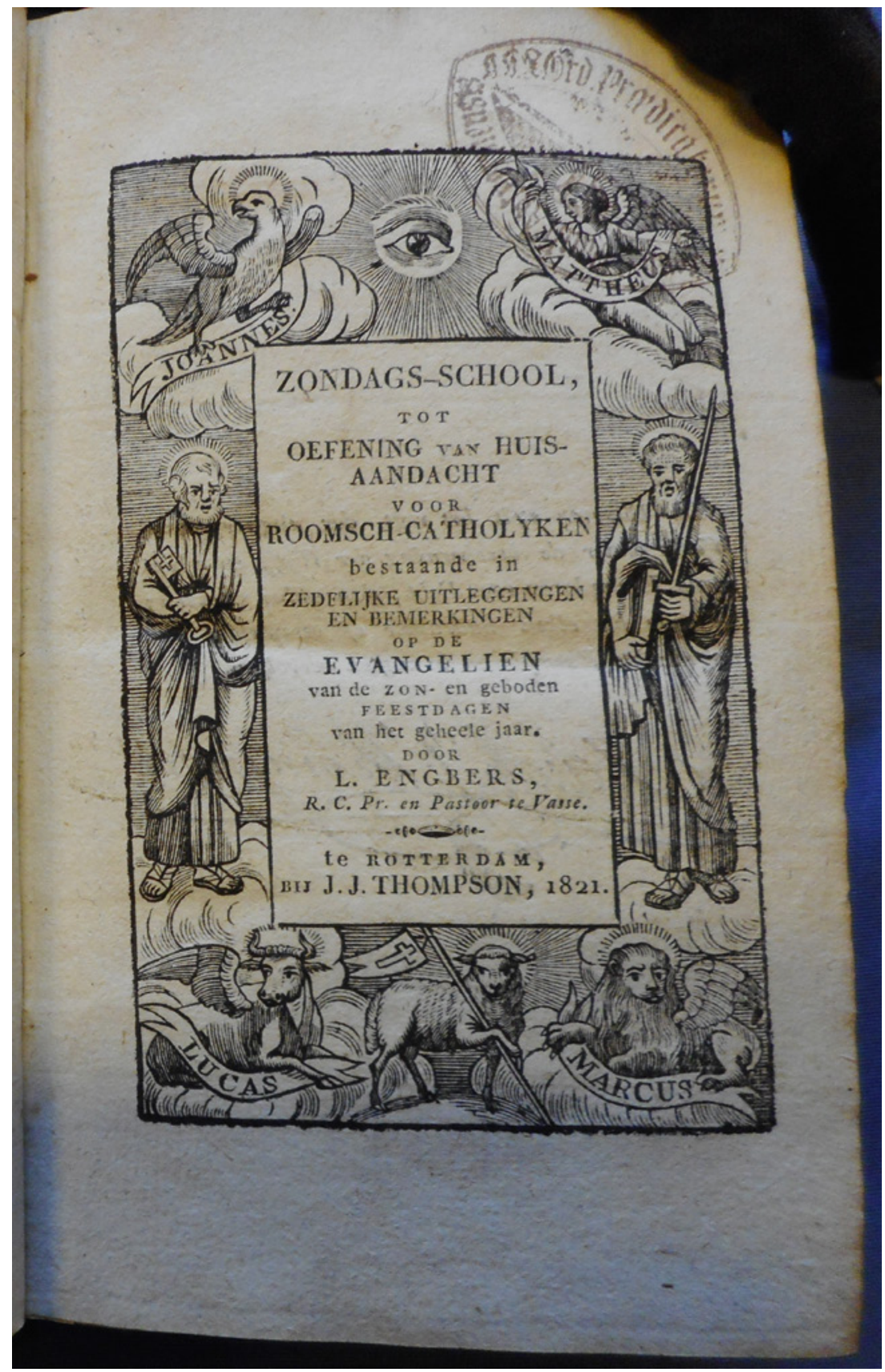

FIGURE 5 Completely revised edition by Lambertus Engbers, first published in 1820/1821 KU LEUVEN LIBRARIES, MAURITS SABBE LIBRARY, GBIB: GODGELEERDHEID (2-028377/B) 
self-confidence of Dutch Catholics, who started building new churches, seminaries and monasteries at the start of the nineteenth century. ${ }^{44}$ The revised version was published in nine versions through $1922,{ }^{45}$ while the old Sondaechs Schoole was reprinted until 1892 with further orthographic revisions and with the addition of prayers for use during Mass, the confessional and at home. ${ }^{46}$

In 1828 , even in the 'old' Sondaechs Schoole, and probably in reaction to the revised version of Sondaechs Schoole, the blackletter was replaced with roman type, the translation of the biblical passages was slightly adapted and the text revised. ${ }^{47}$ The poems, prayers and instructions before and after the main text, which had already been partly omitted by publishers from the South, were now suppressed, also in the North. A comparison of parts of different editions suggests that the text of Sondaechs Schoole remained the same from the seventeenth century until 1828 , when it was completely revised.

According to Theo Clemens, the fact that modernizations were carried out belatedly in northern prints of the Sondaechs Schoole indicates 'a remarkably archaizing tendency' of Dutch Catholicism. ${ }^{48}$ One aspect of this is the use of blackletter, the script of the unlearned, which was generally abandoned earlier for religious literature in the Habsburg Netherlands than in the Northern Netherlands. ${ }^{49}$ Another example of this tendency is the addition of Antonius van Hemert's Vertroostingen in lyden en tegenspoeden (1st ed.: c. 1550) in the edition of 1791 by the heirs of the widow Stichter and in that of $1795[?]$ by Van Tetroode. ${ }^{50}$

44 P. J. Margry, 'Dutch Devotionalisation. Reforming Piety. Grassroots Initiative or Clerical Strategy?', in: The Dynamics of Religious Reform in Northern Europe, c. 1780-1920, ed. A. Jarlert, vol. 5: Reform of Piety (Leuven 2012), pp. 125-56.

45 L. Engbers, Zondagsschool tot oefening van huisaandacht voor roomsch-katholieken, bestaande uit zedelijke uitleggingen en bemerkingen op de evangeliën van de zon-en geboden feestdagen van het geheele jaar. Negende herziene druk ('s-Hertogenbosch 1922).

46 The 1841 edition was expanded with, as the title page says, 'prayers during Holy Mass, morning and evening prayers, confessional and communion prayers and other religious exercises (De gebeden onder de H. misse, morgen- en avond, biecht en communie gebeden, benevens andere godsdienstige oefeningen).

47 Not in 1817 , as Clemens, art. cit. (n.25), p. 61 n. 27, states. The 1817 edition is blackletter.

48 'een merkwaardig archaïsche trek', Clemens, art. cit. (n.25), p. 6 o.

49 T. Clemens, 'De godsdienstigheid in de Nederlanden in de spiegel van de katholieke kerkboeken 1680-1840', vol. I (unpubl. PhD dissertation. Tilburg 1988), pp. 41-2.

$5^{\circ} \quad$ Cf. also Clemens, art. cit. (n.25), p. 6o and n. 29. 
TABLE 1 Comparison of a passage in different editions

\begin{tabular}{lll}
\hline Venlo, widow of & Venlo, widow of & Engbers, Zondagsschool, \\
H. Bontamps, 1817 & H. Bontamps, 1828 & Rotterdam, J. J. Thompson, \\
& & 1821 \\
\hline
\end{tabular}

Op ons Heere

Hemelvaartsdag (p. 182)

Heden, allerliefste

kinderen, zo houden

wy gedagtenis van de

glorieuze Hemelvaart

ons lieve Heere Jezus

Christus, hetwelk een

heerlyk en vrolyke

Feestdag is, en hetwelk

wy in ons heilig Christen

Geloof belyden, als wy

zeggen: Hy is opgevaaren

ten Hemel, en zit ter

regterhand Gods zyns

Vaders almagtig, van

daar zal Hy wederom

komen oordelen over de

levenden en dooden.

\section{FEESTDAG VAN DE FEESTDAG VAN DE \\ HEMELVAART DES HEMELVAART DES \\ HEEREN (p. 162-3) \\ HEEREN (p. 261)}

Heden vieren wij de

gedachtenis van de

glorierijke hemelvaart

onzes Heeren JESUS

CHRISTUS, die nu geze-

ten is aan de regterhand

zijns Vaders.
Heden, op den Feestdag van de glorierijke Hemelvaart onzes Heeren, mogen wij ons in den geest verblijden. Jezus, onze Heiland is, nadat hij het werk der verlossing hier op aarde hadde voltrokken, zegepralend opgeklommen ten hemel; waar hij zit aan de regterhand zijns Vaders, dat is, waar hij met zijnen Vader, van eene en dezelfde Natuur, Heerlijkheid, Magt en Gezag, de heerschappij over het Heelal oefent.

\section{Reception}

We now come to the question of whether Sondaechs Schoole in the Northern Netherlands was received differently than in the South. Did it really serve in the North, as its preface states, as a substitute for the worship service where people were prevented from attending? The editor of the ninth edition of the revised version by Engbers suggests that this was truly the case. He writes of the 'exemplary Catholic forefathers' (brave Katholieke voorvaderen):

If in the days of oppression on Sundays and feast days they could not attend Mass in church at all, or could only with difficulty and sometimes 
with danger hear a silent Mass, then they made good the deficit by holding 'domestic devotions' or 'domestic worship', as it was called. Then the Sunday School came forth: the gospel for the day was read with reverence, along with added explanation and instruction. The head of the household discussed the content with his family, followed by [saying] the rosary, often with different prayers for all sorts of purposes. ${ }^{51}$

The Lord God had blessed this practice and had preserved the forefathers in the Catholic faith, according to the editor. ${ }^{52}$ Although this statement is part of the culture of remembrance of the Dutch Catholics of that time and must therefore be treated critically, there is an indication to confirm it, given by Mathieu G. Spiertz. ${ }^{53}$ Andreas Tiara, a priest from Hemelum in the Dutch province of Friesland, who was active in that area from 166o to 1666, reports on meetings of Catholics in Hindeloopen on Sundays and holidays when no priest could be present to celebrate Mass. On such days, according to Tiara, one of the faithful read a gospel from 'de Sondaghs-Schole'. Beforehand and afterwards, hymns were sung. The meeting ended with a collection for the poor.

Such domestic devotions were probably often practised using Sondaechs Schoole because laypeople had been involved in this substitute form of Mass since the early seventeenth century. The then apostolic vicar of the Dutch Mission, Sasbout Vosmeer, appointed laymen as lectores shortly after 1600. In the absence of a priest, they were to read a homily, the litanies and the prayers on Sunday. If the lector was absent, then the owner of the house where the congregation came together, or a member of the family, was supposed to take on the task..$^{54}$ This practice is redolent of the intensive lay involvement in Dutch Catholicism mentioned at the beginning of this article.

$5^{1} \quad$ 'Als zij in de dagen der verdrukking op Zon- en Feestdagen de godsdienstoefeningen in een kerk in het geheel niet konden bijwonen, of alleen met moeite en soms met gevaar een stille H. Mis konden hooren, dan vulden zij hun tekort aan, en hielden "huiselijke aandacht" of "huisgodsdienst", zooals ze 't noemden. Dan kwam de Zondagsschool voor den dag; het Evangelie van den dag werd met eerbied gelezen met de daarbij gevoegde verklaring en onderrichting; het hoofd van 't gezin besprak den inhoud met de zijnen; daarna volgde de Rozenkrans met vaak nog verschillende gebeden voor allerlei intenties', Engbers, op. cit. (n. 45), p. 2.

$5^{2}$ Engbers, op. cit. (n. 45), p. 2.

53 A.Tiara, Annotationes. Aanteekeningen betreffende de Roomsch-Katholieke Kerk in Friesland sedert de Hervorming tot het jaar 1696, ed. G. H. van Borssum Waalkes (Leeuwarden 1894), p. 53. Cf. M. G. Spiertz, 'De ontwikkelingsgang van de katholieke missie in Friesland 16o91689', Archief voor de Geschiedenis van de Katholieke Kerk in Nederland, 21 (1979), p. 284.

54 M. G. Spiertz, 'Godsdienstig leven van de katholieken in de 17 de eeuw', in: Algemene geschiedenis der Nederlanden, ed. P. Blok et al., vol. 8 (Haarlem 1979), pp. 348. 
The extent to which Sondaechs Schoole was used depended on the local or regional situation of Catholics, which in turn was dependent on the religious policy of the authorities in question. After the Peace of Westphalia, policy was generally more favourable to Catholics than before, but it still differed widely. For example, the Amsterdam City Council was much more beneficial to Catholics than were the states of Zeeland and Friesland. ${ }^{55}$

That books like Sondaechs Schoole were popular in the seventeenth century, at least in Friesland, can perhaps also be deduced from the minutes of a session of the Reformed Synod, held in Franeker in Friesland in 163o. At that meeting, it was decided that papal books, especially those entitled Het evangelium van de Misse (The Gospel of the Mass), should be banned from schools and that the printing and selling of these writings should be forbidden, as H. J. Oldenhof's dissertation on Catholic life in north-western Friesland from 1580 to 1795 shows. This 'Gospel of the Mass' might be a reference to Sondaechs Schoole. ${ }^{56}$ Books similar to that by Jacobsz, known as pericopes, which consisted of excerpts from the Gospels, remained in use at Reformed primary schools during the seventeenth and eighteenth centuries. ${ }^{57}$ This context accounts for the general Christian character of the content of Sondaechs Schoole: the editors and publishers probably wished to avoid offending Reformed ministers and authorities.

However, if Sondaechs Schoole in the Dutch Republic was only used as substitute for Mass, then one would expect that the number of editions would decline during the seventeenth century, given the rise of the number of priests during that century ${ }^{58}$ and the increasing freedom for Catholics; but such a decline was not seen. With regard to the Generality Lands and the Habsburg Netherlands, we lack any indication that Sondaechs Schoole was used as a substitute for the worship service. Nor was this necessary, as Catholics in the former area could attend Catholic worship across the border and those in the latter territory were free to attend Catholic worship; indeed, it was the only form of worship permitted there. On the other hand, Catholics in these areas might have privately read a book during Mass, an activity already prescribed and practised since the Late Middle Ages. ${ }^{59}$

55 G. Ackermans, Herders en huurlingen. Bisschoppen en priesters in de Republiek (1663-1705) (Amsterdam 2003) pp. 181-6.

$56 \quad$ H. J. Oldenhof, In en om de schuilkerkjes van Noordelijk Westergo. Katholiek leven in Frieslands Noordwesthoek onder de Republiek (1580-1795) (Assen 1967), p. 214.

57 J. Salman, Populair drukwerk in de Gouden Eeuw. De almanak als lectuur en handelswaar (Zutphen 1999), p. 149. On Sondaechs Schoole: Salman, Populair drukwerk, pp. 152-3.

$5^{8}$ Lenarduzzi, op. cit. (n.10), p. 9. From 70 priests in 1602 to 360 secular priests and 140 regular clergy in 165 . 
Thus, no significant differences in readership or in the manner of reading of Sondaechs Schoole seem to have existed between the North and the South. Copies from both the North and South were owned by laypeople as well as by clergy or religious communities, as can be seen by inscriptions and other indications of provenance. In addition, copies from both areas are often bound in black leather covers with the letters IHS on the front plate, sometimes with iron locks. This is an indication of the value attributed to the book. It was obviously treated as a liturgical work.

\section{Conclusion}

Sondaechs Schoole is an interesting product of the lay-clerical cooperation which is such a characteristic feature of early modern Dutch Catholicism. A comparison of its printing history and reception both in the Northern and Southern Netherlands reveals two dimensions which may be typical of book culture and reading culture. First, there is the fact that Dutch publishers, printers and/or editors show much more conservativism with respect to the layout of the title page, typography and the structure of the book than their Southern colleagues. The latter were already making significant changes in this regard during the eighteenth century. The traditionalism noted may be explained by the fact that whereas Roman Catholics in the South were the dominant culture, in the North they formed a subculture. Thus, we may regard the approach of the publishers, printers and/or editors as a means towards demarcating their subcultural identity from the dominant Protestant culture.

However, other factors may have also played a role, such as social factors on the part of the producers. Lienke Leuven, for example, has shown with regard to the Amsterdam printers and publishers that their lower middle-class status in the latter half of the eighteenth century led to a conservative attitude in their choice of books to publish or print. ${ }^{60}$ An archaizing tendency similar to that of the Catholics also took place among conservative Reformed publishers in the Netherlands in the nineteenth century, namely, the choice of blackletter, probably as a demarcation from more liberal Reformed colleagues. ${ }^{61}$

$60 \quad$ L. P. Leuven, De boekhandel te Amsterdam door katholieken gedreven tijdens de Republiek (Epe 1951), p. 53 .

$61 C f$. the example of C. Love, Theologia practica, dat is al de theologische werken (Utrecht [c. 1863]). Remarkably, the spelling has been adapted to contemporary standards. $C f$. F. W. Huisman, 'De bibliografie van de Nederlandstalige werken van Christopher Love', in: Nederlandse liefde voor Christopher Love (1618-1651). Studies over het vertaalde werk van een presbyteriaanse puritein, ed. W. J. op 't Hof and F.W. Huisman (Amstelveen 2013), pp. $144-5$, p. 207. 
Clemens considers the aforementioned conservative approach an indication of a 'strong traditional religiosity' of Dutch Catholicism. This religious stance should rather, in my opinion, be considered a conscious agency of forming memory, a process that has been analysed in the work of Astrid Erll and others on cultural memory. ${ }^{62}$ That scholarship can aid our understanding of the choices and strategies of publishers and editors. First, the publishers repeatedly re-used the title page (even in the revision of 1820/1821), typography and contents of Sondaechs Schoole. This can be considered as a sort of remediation (a continuous transcription of memory content into different media, such as the remediation of print, radio, TV, film, etc. now seen on the Internet). Although the title page of Sondaechs Schoole was not transcribed into another medium, its typography and contents were represented over decades and centuries in a manner comparable with the process of remediation on the title page, and this is exactly 'what creates a powerful site of memory'.63 Second, memory of the Sondaechs Schoole was formed by the inclusion of the miraculous story in the preface of the old version, as well as by the revisor Engbers recalling the use of the book by the 'exemplary Catholic forefathers' during the 'days of oppression'.

However, these were the strategies of publishers, printers and editors, and we should be cautious to extend this approach towards characterizing the stance of Dutch Catholicism in general, as Clemens seems to do. With this borne in mind, the reception of Sondaechs Schoole in the North in some ways reveals no differences from that in the South, as in both territories the booklet was in possession of the same kind of persons and communities, who used the same kind of book bindings. Thus, more research on other Dutch Catholic religious books and on the religiosity of their readers is needed to reveal the religious stances of publishers, editors and readers of books. Moreover, caution is advisable, given the multiple identities that Pollmann discerned among

62 A. Erll and A. Rigney, Mediation, Remediation, and the Dynamics of Cultural Memory (Berlin/New York 2009); A. Erll, Kollektives Gedächtnis und Erinnerungskulturen. Eine Einführung, 3rd., rev. and exp. ed. (Stuttgart 2017); A. Erll., 'Media and the Dynamics of Memory. From Cultural Paradigms to Transcultural Premediation', in: Handbook of Culture and Memory, ed. B. Wagoner (New York 2018), pp. 305-24, there pp. 312-5. Thanks to Prof Dr Astrid Erll (Frankfurt/Main) for these references. On memory in the early modern Republic and Europe in general, see: J. van der Steen, Memory wars in the Low Countries, 1566-1700 (Leiden 2015); J. Pollmann, Memory in Early Modern Europe, 15001800 (Oxford 2017). On memory of early modern Dutch Catholicism, see J. Geraerts, 'Early Modern Catholicism and Its Historiography. Innovation, Revitalization, and Integration,' Church History and Religious Culture, 97/3-4 (2017), pp. 381-92, pp. 387-9o, including the references. 
early modern Catholics and given the multi-layered identities which scholarship has discovered among Dutch Catholics.

A second feature of the reading culture of Dutch Catholics may be the fact that some of them sometimes used the Sondaechs Schoole as a substitute for Mass. ${ }^{64}$ However, the book was not only used in this way in the Northern Netherlands because it remained in frequent publication after 1650 as the freedom of Catholics grew. Moreover, it was probably not used as a substitute for Mass in the Generality Lands and in the Habsburg Netherlands. In the former territories, Catholics did not need the book as a substitute for Mass, as they could attend Catholic worship in the adjoining Habsburg Netherlands or in the Catholic enclaves within the Dutch Republic. In the latter area, the Habsburg Netherlands, Catholicism was allowed exclusively.

Strikingly, Sondaechs Schoole was not published in the Generality Lands until the late eighteenth century. This may be explained by the lack of capable printing presses in these lands until then. Overall, the reading culture of Sondaechs Schoole within early modern Dutch Catholicism is similar to that of Protestants in the Habsburg Lands and that of English Catholics, as we discern the same processes in each: the canonization of books and their use as a substitute for face-to-face encounters and worship. However, apart from the miraculous story in the preface about a revelation regarding Sondaechs Schoole and about its converting impact, the book seems not to have been used as a relic. Nevertheless, the magical use of religious books may not be an exclusive feature of religious subcultures, as it also occurred among dominant cultures. ${ }^{65}$ The case study of Sondaechs Schoole indicates in addition that a conservative approach towards layout, typography and contents - a kind of remediation

64 Catholics also used other forms of piety, such as the Rosary, as a supplement to the reading of writings. In addition, sacred places were very important for Catholics, both in England and the Netherlands. Examples are holy wells, ruined chapels, holy sites that were stripped of sacred imagery or object and spiritual pilgrimages, $c f$. A. Walsham, 'Holywell. Contesting Sacred Space in Post-Reformation Wales', in: Sacred Space in Early Modern Europe, ed. W. Coster and A. Spicer (Cambridge 2005), pp. 211-36; A. Walsham, 'Beads, Books and Bare Ruined Choirs. Transmutations of Catholic Ritual Life in Protestant England', in: Kaplan et al., op. cit. (n. 14), pp. 103-22. On the Dutch situation, see: P. J. Margry, 'Processie versus stille omgang. Het probleem van de openbare godsdienstoefening buiten gebouwen en besloten plaatsen', Holland. Historisch Tijdschrift, 25 (1993), pp. 174-196; W. Frijhoff, Embodied Belief. Ten Essays on Religious Culture in Dutch History (Hilversum 2002); Lenarduzzi, op. cit. (n. 10), esp. pp. 143-244.

65 Cf. F. A. van Lieburg, 'De bijbel als orakelboek. Bibliomantie in de protestante traditie', in: Materieel christendom. Religie en materiële cultuur in West Europa, ed. A. L. Molendijk (Hilversum 2003), pp. 81-105, and the references there. 
by which memory is formed - may be typical of the printing culture of a religious subculture.

To conclude, in order to clarify further to what extent religious subcultures had a specific book culture and reading culture, more research needs to be done, and should also account for the dimension of the distribution of books. In addition, other writings besides Sondaechs Schoole should be analysed comparatively. Works that could thus be usefully compared with Sondaechs Schoole are writings that deal with Scripture, such as books of hours, translations of parts of Scripture, communion preparation books and prayer books. ${ }^{66}$

\section{Acknowledgement}

This is an expanded version of my Habilitation lecture at the University of Bremen held on October 23rd, 2019. I would like to express my gratitude to Dr. Theo Clemens for the data which he provided me from his own research, as well as to the members of the Habilitation committee for their useful comments on my lecture. The data for this article were largely collected during a stay at the Maurits Sabbe library and the Special Collections of the University Library of the KU Leuven provided by a ReIReS transnational access fellowship during September 2019. Finally, I would like to express thanks to Dr John Exalto, Prof. Dr. Veerle Fraeters and Drs. F. W. Huisman for their comments on an earlier version, as well as to Alexander Thomson MA for correcting the English of this contribution.

\section{Appendix}

Overview of Editions of Heyman Jacobsz's Sondaechs Schoole with Notes on Title Pages and Contents

Note:

- Single editions of $\mathrm{H}$ are not included

- $\mathrm{Y}$ and $\mathrm{N}$ indicate whether the part in question is included in the edition concerned or not

- Question marks denote that the edition in question has not been consulted or that the part concerned has not been found in a copy thus far

66 Clemens, art. cit. (n. 24), pp. 57-8. 


\begin{tabular}{|c|c|c|c|c|c|c|c|}
\hline Place & $\begin{array}{l}\text { Publisher/ } \\
\text { printer }\end{array}$ & Year & $\begin{array}{l}\text { Description } \\
\text { of title page }\end{array}$ & $\begin{array}{l}\text { List of } \\
\text { moveable } \\
\text { holidays } \\
\text { in } \\
\text { Mechelen } \\
\text { diocese }\end{array}$ & $\begin{array}{l}\text { List of } \\
\text { fixed } \\
\text { holidays } \\
\text { in } \\
\text { Mechelen } \\
\text { diocese }\end{array}$ & Preface & $\begin{array}{l}\text { Preface } \\
\text { publisher/ } \\
\text { printer }\end{array}$ \\
\hline
\end{tabular}

\begin{tabular}{|c|c|c|c|c|c|c|c|}
\hline $\begin{array}{l}\text { Leuven } \\
\text { [= Amsterdam] }\end{array}$ & Fabri, C. & 1623 & $\begin{array}{l}\text { JHWH, } \\
\text { separate } \\
\text { bottom of } \\
\text { woodcut, } \\
\text { order of } \\
\text { evangelists } \\
\text { (above-below, } \\
\text { left-right) } \\
\text { Jn, Mt, Lk, } \\
\text { Mk }\end{array}$ & $\mathrm{N}$ & $\mathrm{N}$ & $\mathrm{Y}$ & $\mathrm{N}$ \\
\hline $\begin{array}{l}\text { Leuven } \\
{[=\text { Amsterdam }]}\end{array}$ & $\begin{array}{l}\text { Fabri, C.; } \\
\text { Cool, C. D. }\end{array}$ & $1646 ?$ & $\begin{array}{l}\text { IHS, Jn, Mt, } \\
\text { Lk, Mk }\end{array}$ & $\mathrm{N}$ & $\mathrm{N}$ & $\mathrm{Y}$ & $\mathrm{Y}$ \\
\hline $\begin{array}{l}\text { Leuven } \\
{[=\text { Haarlem }]}\end{array}$ & Braau, N. & 1675 & $\begin{array}{l}\text { JHWH, } \\
\text { separate } \\
\text { bottom of } \\
\text { woodcut, } \\
\text { Mt, Jn, Lk, } \\
\text { Mk, red and } \\
\text { black letters }\end{array}$ & $\mathrm{N}$ & $\mathrm{N}$ & $\mathrm{Y}$ & $\mathrm{Y}$ \\
\hline $\begin{array}{l}\text { Leuven } \\
\text { [= Amsterdam] }\end{array}$ & $\begin{array}{l}\text { Fabri, C. } \\
\text { [= Cool II, } \\
\text { C. D. }]\end{array}$ & c. 1675 & $\begin{array}{l}\text { IHs, no } \\
\text { separate } \\
\text { bottom, Jn, } \\
\text { Mt, Lk, Mk }\end{array}$ & $\mathrm{N}$ & $\mathrm{N}$ & $\mathrm{Y}$ & $\mathrm{Y}$ \\
\hline $\begin{array}{l}\text { Leuven } \\
\text { [= Amsterdam] }\end{array}$ & Cool II, C. D. & 1678 & $\begin{array}{l}\text { JHWH, } \\
\text { separate } \\
\text { bottom, Mt, } \\
\text { Jn, Lk, Mk, } \\
\text { cross }\end{array}$ & $\mathrm{N}$ & $\mathrm{N}$ & $\mathrm{Y}$ & $\mathrm{Y}$ \\
\hline
\end{tabular}




\begin{tabular}{|c|c|c|c|c|c|c|}
\hline $\begin{array}{l}\text { Poem for } \\
\text { school- } \\
\text { children }\end{array}$ & $\begin{array}{l}\text { Poem } \\
\text { Kinderen } \\
\text { sinnen }\end{array}$ & $\begin{array}{l}\text { Instructions } \\
\text { for prayer, } \\
\text { model } \\
\text { prayers }\end{array}$ & $\begin{array}{l}\text { 'Nota: } \\
\text { instruction } \\
\text { for if more } \\
\text { than } 24 \\
\text { Sundays after } \\
\text { Pentecost }\end{array}$ & $\begin{array}{l}\text { Tot den lezer: } \\
\text { instructions } \\
\text { for Sunday } \\
\text { observance }\end{array}$ & $\begin{array}{l}\text { Profytelicke } \\
\text { Puncten } \\
\text { instructions } \\
\text { on godly } \\
\text { living }\end{array}$ & $\begin{array}{l}\text { Poem } \\
\text { Kinderen } \\
\text { sinnen and } \\
\text { poems for } \\
\text { parents } \\
\text { and } \\
\text { teachers }\end{array}$ \\
\hline $\mathrm{N}$ & Y & $\mathrm{N}$ & $\mathrm{N}$ & Y & $\mathrm{Y}$ & $\mathrm{N}$ \\
\hline
\end{tabular}

$\begin{array}{lllllll}\mathrm{Y} & \mathrm{N} & \mathrm{Y} & \mathrm{Y} & \mathrm{Y} & \mathrm{Y} & \mathrm{Y} \\ \mathrm{Y} & \mathrm{N} & \mathrm{Y} & \mathrm{Y} & \mathrm{Y} & \mathrm{Y} & \mathrm{Y}\end{array}$

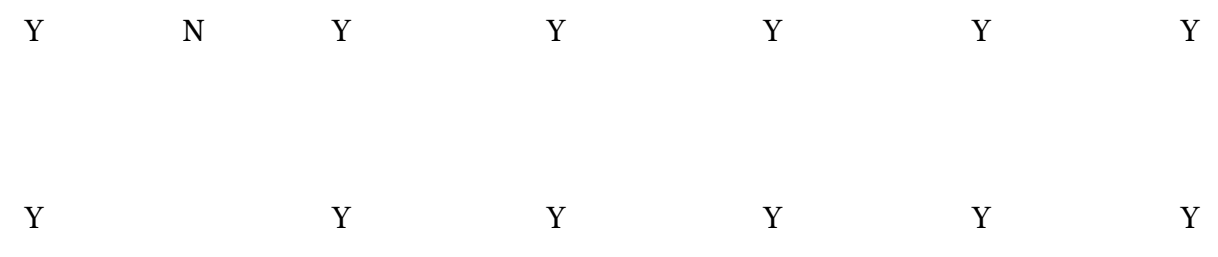


(cont.)

\begin{tabular}{|c|c|c|c|c|c|c|c|}
\hline Place & $\begin{array}{l}\text { Publisher/ } \\
\text { printer }\end{array}$ & Year & $\begin{array}{l}\text { Description } \\
\text { of title page }\end{array}$ & $\begin{array}{l}\text { List of } \\
\text { moveable } \\
\text { holidays } \\
\text { in } \\
\text { Mechelen } \\
\text { diocese }\end{array}$ & $\begin{array}{l}\text { List of } \\
\text { fixed } \\
\text { holidays } \\
\text { in } \\
\text { Mechelen } \\
\text { diocese }\end{array}$ & Preface & $\begin{array}{l}\text { Preface } \\
\text { publisher/ } \\
\text { printer }\end{array}$ \\
\hline
\end{tabular}

\begin{tabular}{lll}
\hline Leuven & de Groot, M. 1680 & JHWH, \\
[=Amsterdam] & separate \\
& bottom, Mt, \\
& Jn, Lk, Mk, \\
& cross, red \\
& and black \\
& letters
\end{tabular}

Antwerp Stichter, C. c. 1700 IHS, no

[= Amsterdam $]$

separate

bottom, Jn,

$\mathrm{Mt}, \mathrm{Lk}, \mathrm{Mk}$,

cross, red and

black letters

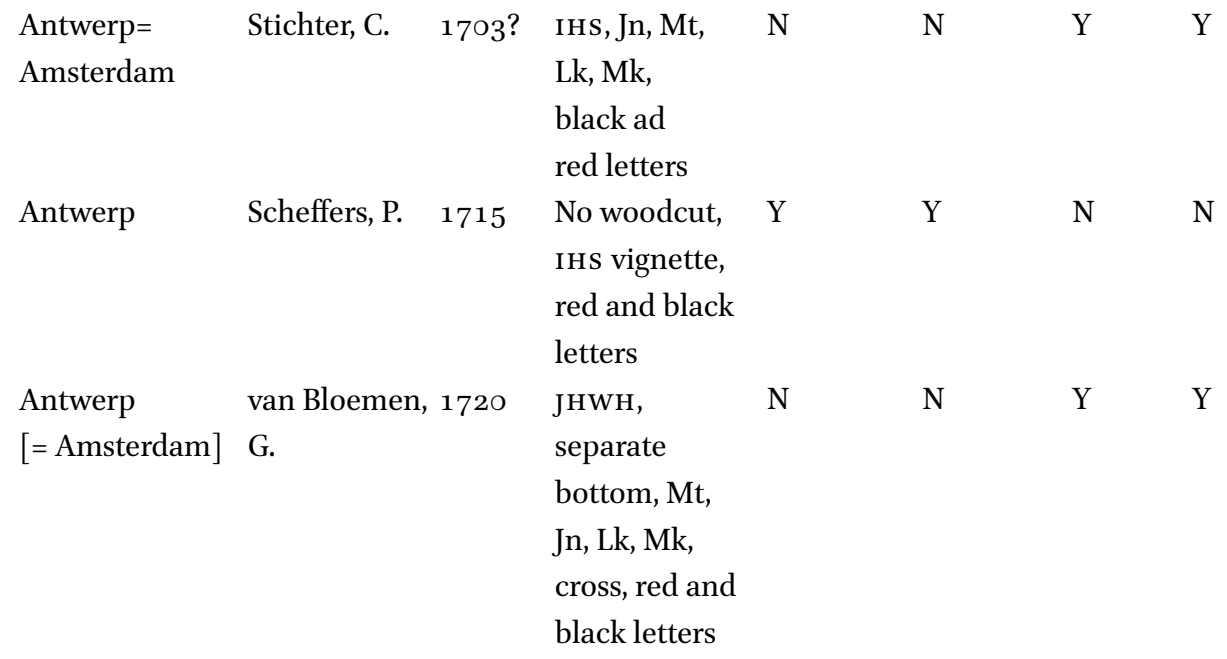

$\begin{array}{lllllll}\text { Antwerp } & \text { Scheffers, P. } & 1737 & ? & ?\end{array}$ 


\begin{tabular}{|c|c|c|c|c|c|c|}
\hline $\begin{array}{l}\text { Poem for } \\
\text { school- } \\
\text { children }\end{array}$ & $\begin{array}{l}\text { Poem } \\
\text { Kinderen } \\
\text { sinnen }\end{array}$ & $\begin{array}{l}\text { Instructions } \\
\text { for prayer, } \\
\text { model } \\
\text { prayers }\end{array}$ & $\begin{array}{l}\text { 'Nota: } \\
\text { instruction } \\
\text { for if more } \\
\text { than } 24 \\
\text { Sundays after } \\
\text { Pentecost }\end{array}$ & $\begin{array}{l}\text { Tot den lezer: } \\
\text { instructions } \\
\text { for Sunday } \\
\text { observance }\end{array}$ & $\begin{array}{l}\text { Profiytelicke } \\
\text { Puncten } \\
\text { instructions } \\
\text { on godly } \\
\text { living }\end{array}$ & $\begin{array}{l}\text { Poem } \\
\text { Kinderen } \\
\text { sinnen and } \\
\text { poems for } \\
\text { parents } \\
\text { and } \\
\text { teachers }\end{array}$ \\
\hline $\mathrm{Y}$ & $\mathrm{N}$ & $\mathrm{Y}$ & Y & $\mathrm{Y}$ & $Y$ & $\mathrm{Y}$ \\
\hline
\end{tabular}

? $\quad$ ?

?

?

?

$?$

?

Y

$\mathrm{N}$

Y

Y

Y

Y

Y

N

N

N

Y

Y

Y

N

Y

N

Y

Y

Y

Y

Y 
(cont.)

\begin{tabular}{|c|c|c|c|c|c|c|c|}
\hline Place & $\begin{array}{l}\text { Publisher/ } \\
\text { printer }\end{array}$ & Year & $\begin{array}{l}\text { Description } \\
\text { of title page }\end{array}$ & $\begin{array}{l}\text { List of } \\
\text { moveable } \\
\text { holidays } \\
\text { in } \\
\text { Mechelen } \\
\text { diocese }\end{array}$ & $\begin{array}{l}\text { List of } \\
\text { fixed } \\
\text { holidays } \\
\text { in } \\
\text { Mechelen } \\
\text { diocese }\end{array}$ & Preface & $\begin{array}{l}\text { Preface } \\
\text { publisher/ } \\
\text { printer }\end{array}$ \\
\hline
\end{tabular}

\begin{tabular}{llllllll}
\hline Antwerp & Stichter, & 1739 & IHs, no & N & N & Y & Y \\
[= Amsterdam] & erfg. wed. C. & separate & & & \\
& & bottom, Jn, & & \\
& Mt, Lk, Mk, \\
& cross, red and \\
& black letters
\end{tabular}

Antwerp van Soest, F. 1748

IHs, partly

Roman

typeface, no

separate

bottom, Jn,

$\mathrm{Mt}, \mathrm{Lk}, \mathrm{Mk}$,

cross

Antwerp

Stichter,

$175^{\circ}$

?

$?$

Y

Y Y

[= Amsterdam $]$ heirs of

widow $\mathrm{C}$.

Antwerp [='s- Scheffers,

IHS, no

Y

Y

Y

Y

Hertogenbosch]

separate

bottom, Jn,

$\mathrm{Mt}, \mathrm{Lk}, \mathrm{Mk}$,

cross

$\begin{array}{lll}\text { Antwerp } & \text { Stichter, heirs } 175^{1} & \text { IHS, no } \\ \text { [=Amsterdam] } & \text { widow C. } & \text { separate } \\ & & \text { bottom, Jn, } \\ & \text { Mt, Lk, Mk, } \\ & \text { cross, red and } \\ & \text { black letters }\end{array}$

Antwerp

van Soest, H. 1761

?

Y

Y

Y $\quad \mathrm{Y}$ 


\begin{tabular}{|c|c|c|c|c|c|c|}
\hline $\begin{array}{l}\text { Poem for } \\
\text { school- } \\
\text { children }\end{array}$ & $\begin{array}{l}\text { Poem } \\
\text { Kinderen } \\
\text { sinnen }\end{array}$ & $\begin{array}{l}\text { Instructions } \\
\text { for prayer, } \\
\text { model } \\
\text { prayers }\end{array}$ & $\begin{array}{l}\text { 'Nota: } \\
\text { instruction } \\
\text { for if more } \\
\text { than } 24 \\
\text { Sundays after } \\
\text { Pentecost }\end{array}$ & $\begin{array}{l}\text { Tot den lezer: } \\
\text { instructions } \\
\text { for Sunday } \\
\text { observance }\end{array}$ & $\begin{array}{l}\text { Profiytelicke } \\
\text { Puncten } \\
\text { instructions } \\
\text { on godly } \\
\text { living }\end{array}$ & $\begin{array}{l}\text { Poem } \\
\text { Kinderen } \\
\text { sinnen and } \\
\text { poems for } \\
\text { parents } \\
\text { and } \\
\text { teachers }\end{array}$ \\
\hline$Y$ & $\mathrm{~N}$ & $Y$ & $\mathrm{Y}$ & $\mathrm{Y}$ & $\mathrm{Y}$ & $\mathrm{Y}$ \\
\hline
\end{tabular}

$\begin{array}{lllllll}\mathrm{N} & \mathrm{N} & \mathrm{N} & \mathrm{Y} & \mathrm{Y} & \mathrm{Y} & \mathrm{Y}\end{array}$

Y

Y

Y

Only

poems for

parents

and

teachers

Y

N

Y

Y

Y

Y

Y

N $\mathrm{N}$

N

Y

Y

Y

N 
(cont.)

\begin{tabular}{|c|c|c|c|c|c|c|c|}
\hline Place & $\begin{array}{l}\text { Publisher/ } \\
\text { printer }\end{array}$ & Year & $\begin{array}{l}\text { Description } \\
\text { of title page }\end{array}$ & $\begin{array}{l}\text { List of } \\
\text { moveable } \\
\text { holidays } \\
\text { in } \\
\text { Mechelen } \\
\text { diocese }\end{array}$ & $\begin{array}{l}\text { List of } \\
\text { fixed } \\
\text { holidays } \\
\text { in } \\
\text { Mechelen } \\
\text { diocese }\end{array}$ & Preface & $\begin{array}{l}\text { Preface } \\
\text { publisher/ } \\
\text { printer }\end{array}$ \\
\hline
\end{tabular}

\begin{tabular}{|c|c|c|c|c|c|c|c|}
\hline $\begin{array}{l}\text { Antwerp } \\
{[=\text { Amsterdam }]}\end{array}$ & $\begin{array}{l}\text { Stichter, } \\
\text { heirs of } \\
\text { widow C. }\end{array}$ & 1761 & $\begin{array}{l}\text { IHS, no } \\
\text { separate } \\
\text { bottom, Jn, } \\
\text { Mt, Lk, Mk, } \\
\text { cross, red and } \\
\text { black letters }\end{array}$ & $\mathrm{N}$ & $\mathrm{N}$ & $\mathrm{Y}$ & $\mathrm{Y}$ \\
\hline $\begin{array}{l}\text { 's- Hertogen- } \\
\text { bosch }\end{array}$ & Scheffers, J. & 1764 & $\begin{array}{l}\text { No woodcut, } \\
\text { IHS vignette }\end{array}$ & $\mathrm{N}$ & $\mathrm{N}$ & $\mathrm{Y}$ & $\mathrm{Y}$ \\
\hline Antwerp & $\begin{array}{l}\text { van Soest, } \\
\text { J. H. }\end{array}$ & 1766 & $\begin{array}{l}\text { IHs, no } \\
\text { separate } \\
\text { bottom, Jn, } \\
\text { Mt, Lk, Mk, } \\
\text { cross }\end{array}$ & $\mathrm{Y}$ & Y & $?$ & $?$ \\
\hline Antwerp & $\begin{array}{l}\text { Crayenschot, } \\
\text { Theodorus }\end{array}$ & 1771 & $?$ & $?$ & $?$ & $?$ & $?$ \\
\hline $\begin{array}{l}\text { Antwerp } \\
{[=\text { Amsterdam }]}\end{array}$ & $\begin{array}{l}\text { Stichter, } \\
\text { heirs of } \\
\text { widow C. }\end{array}$ & 1772 & $\begin{array}{l}\text { IHS, no } \\
\text { separate } \\
\text { bottom, Jn, } \\
\text { Mt, Lk, Mk, } \\
\text { cross, red and } \\
\text { black letters }\end{array}$ & $\mathrm{N}$ & $\mathrm{N}$ & $\mathrm{Y}$ & $\mathrm{Y}$ \\
\hline Antwerp & Parys, P. Y. & 1774 & $\begin{array}{l}\text { No woodcut, } \\
\text { partly Roman } \\
\text { typeface }\end{array}$ & $\mathrm{Y}$ & $\mathrm{N}$ & $\mathrm{Y}$ & $\mathrm{Y}$ \\
\hline Antwerp & Vinck, F. I. & 1778 & $\begin{array}{l}\text { No woodcut, } \\
\text { fully Roman } \\
\text { typeface }\end{array}$ & $\mathrm{Y}$ & $\mathrm{N}$ & $\mathrm{Y}$ & $\mathrm{Y}$ \\
\hline
\end{tabular}




\begin{tabular}{|c|c|c|c|c|c|c|}
\hline $\begin{array}{l}\text { Poem for } \\
\text { school- } \\
\text { children }\end{array}$ & $\begin{array}{l}\text { Poem } \\
\text { Kinderen } \\
\text { sinnen }\end{array}$ & $\begin{array}{l}\text { Instructions } \\
\text { for prayer, } \\
\text { model } \\
\text { prayers }\end{array}$ & $\begin{array}{l}\text { 'Nota: } \\
\text { instruction } \\
\text { for if more } \\
\text { than } 24 \\
\text { Sundays after } \\
\text { Pentecost }\end{array}$ & $\begin{array}{l}\text { Tot den lezer: } \\
\text { instructions } \\
\text { for Sunday } \\
\text { observance }\end{array}$ & $\begin{array}{l}\text { Profiytelicke } \\
\text { Puncten } \\
\text { instructions } \\
\text { on godly } \\
\text { living }\end{array}$ & $\begin{array}{l}\text { Poem } \\
\text { Kinderen } \\
\text { sinnen and } \\
\text { poems for } \\
\text { parents } \\
\text { and } \\
\text { teachers }\end{array}$ \\
\hline$Y$ & $\mathrm{~N}$ & Y & Y & $\mathrm{Y}$ & $\mathrm{Y}$ & $\mathrm{Y}$ \\
\hline
\end{tabular}

$\begin{array}{lllllll}\mathrm{Y} & \mathrm{N} & \mathrm{Y} & \mathrm{Y} & \mathrm{Y} & \mathrm{Y} & \mathrm{Y} \\ ? & ? & ? & ? & ? & ? & \end{array}$

\begin{tabular}{|c|c|c|c|c|c|c|}
\hline$?$ & $?$ & $?$ & $?$ & $?$ & $?$ & $?$ \\
\hline $\mathrm{Y}$ & $\mathrm{N}$ & Y & $\mathrm{Y}$ & Y & Y & $\mathrm{Y}$ \\
\hline $\mathrm{N}$ & $\mathrm{N}$ & $\mathrm{N}$ & $\mathrm{N}$ & $\mathrm{Y}$ & Y & $\mathrm{Y}$ \\
\hline $\mathrm{N}$ & $\mathrm{N}$ & $\mathrm{N}$ & Y & Y & Y & $\begin{array}{l}\text { Only } \\
\text { poems for } \\
\text { parents } \\
\text { and } \\
\text { teachers }\end{array}$ \\
\hline
\end{tabular}


(cont.)

\begin{tabular}{|c|c|c|c|c|c|c|c|}
\hline Place & $\begin{array}{l}\text { Publisher/ } \\
\text { printer }\end{array}$ & Year & $\begin{array}{l}\text { Description } \\
\text { of title page }\end{array}$ & $\begin{array}{l}\text { List of } \\
\text { moveable } \\
\text { holidays } \\
\text { in } \\
\text { Mechelen } \\
\text { diocese }\end{array}$ & $\begin{array}{l}\text { List of } \\
\text { fixed } \\
\text { holidays } \\
\text { in } \\
\text { Mechelen } \\
\text { diocese }\end{array}$ & Preface & $\begin{array}{l}\text { Preface } \\
\text { publisher/ } \\
\text { printer }\end{array}$ \\
\hline
\end{tabular}

\begin{tabular}{llllllll}
\hline Antwerp & Stichter, & 1783 & IHs, no & N & N & Y & Y \\
[= Amsterdam] $]$ & heirs of & & & & \\
& separate & & \\
& bottom, Jn, \\
& Mt, Lk, Mk, \\
& cross, red and \\
& black letters
\end{tabular}

F. J.

Antwerp

van Tetroode, 1788 ?

?

? ? ?

F. J.

Venlo/Geldern Bontamps,

c. 1789 IHS, no

$\mathrm{N} \quad \mathrm{N}$

Y Y

widow $\mathrm{H}$;;

separate

Bontamps, F.; bottom, Mt,

Bontamps, C. Jn, Mk, Lk,

crown

Amsterdam van Tetroode, 1791[?] ?

F. J.

Antwerp

Stichter,

1791

IHS, no

$\mathrm{N}$

$\mathrm{N}$

Y

[= Amsterdam $]$ heirs of

separate

widow $\mathrm{C}$.

bottom, Jn,

$\mathrm{Mt}, \mathrm{Lk}, \mathrm{Mk}$,

cross, red and

black letters

Antwerp

van Tetroode, 1795[?]

$\mathrm{N}$

$\mathrm{N}$

Y Y

[= Amsterdam $]$

separate

bottom, Jn,

$\mathrm{Mt}, \mathrm{Lk}, \mathrm{Mk}$,

cross, red and

black letters 


\begin{tabular}{|c|c|c|c|c|c|c|}
\hline $\begin{array}{l}\text { Poem for } \\
\text { school- } \\
\text { children }\end{array}$ & $\begin{array}{l}\text { Poem } \\
\text { Kinderen } \\
\text { sinnen }\end{array}$ & $\begin{array}{l}\text { Instructions } \\
\text { for prayer, } \\
\text { model } \\
\text { prayers }\end{array}$ & $\begin{array}{l}\text { 'Nota: } \\
\text { instruction } \\
\text { for if more } \\
\text { than } 24 \\
\text { Sundays after } \\
\text { Pentecost }\end{array}$ & $\begin{array}{l}\text { Tot den lezer: } \\
\text { instructions } \\
\text { for Sunday } \\
\text { observance }\end{array}$ & $\begin{array}{l}\text { Profiytelicke } \\
\text { Puncten } \\
\text { instructions } \\
\text { on godly } \\
\text { living }\end{array}$ & $\begin{array}{l}\text { Poem } \\
\text { Kinderen } \\
\text { sinnen and } \\
\text { poems for } \\
\text { parents } \\
\text { and } \\
\text { teachers }\end{array}$ \\
\hline$Y$ & Y & $\mathrm{Y}$ & $\mathrm{Y}$ & $\mathrm{Y}$ & $\mathrm{Y}$ & $Y$ \\
\hline
\end{tabular}

$\begin{array}{lllllll}? & ? & ? & ? & ? & ? & ? \\ ? & ? & ? & ? & ? & ? & \\ \mathrm{Y} & \mathrm{N} & \mathrm{Y} & \mathrm{Y} & \mathrm{Y} & \mathrm{Y} & \\ & & & & & \\ & & & & & & \\ & & & & & & \\ ? & ? & ? & & & & \\ \mathrm{Y} & \mathrm{N} & \mathrm{Y} & \mathrm{Y} & \mathrm{Y} & \mathrm{Y} & \mathrm{Y}\end{array}$


(cont.)

\begin{tabular}{|c|c|c|c|c|c|c|c|}
\hline Place & $\begin{array}{l}\text { Publisher/ } \\
\text { printer }\end{array}$ & Year & $\begin{array}{l}\text { Description } \\
\text { of title page }\end{array}$ & $\begin{array}{l}\text { List of } \\
\text { moveable } \\
\text { holidays } \\
\text { in } \\
\text { Mechelen } \\
\text { diocese }\end{array}$ & $\begin{array}{l}\text { List of } \\
\text { fixed } \\
\text { holidays } \\
\text { in } \\
\text { Mechelen } \\
\text { diocese }\end{array}$ & Preface & $\begin{array}{l}\text { Preface } \\
\text { publisher/ } \\
\text { printer }\end{array}$ \\
\hline
\end{tabular}

\begin{tabular}{|c|c|c|c|c|c|c|}
\hline Venlo/Geldern & $\begin{array}{l}\text { Bontamps, } \\
\text { widow H.; } \\
\text { Bontamps, F.; } \\
\text { Bontamps, C. }\end{array}$ & 1797 & $\begin{array}{l}\text { JHWH, no } \\
\text { separate } \\
\text { bottom, Jn, } \\
\text { Mt, Lk, Mk }\end{array}$ & $\mathrm{N}$ & $\mathrm{N}$ & $\mathrm{Y}$ \\
\hline Antwerp & Vinck, J. N. & $\begin{array}{l}{[1799-} \\
1813]\end{array}$ & $\begin{array}{l}\text { No woodcut, } \\
\text { Roman } \\
\text { typeface }\end{array}$ & Y & $\mathrm{N}$ & $\mathrm{Y}$ \\
\hline
\end{tabular}

\begin{tabular}{|c|c|c|c|c|c|c|}
\hline $\begin{array}{l}\text { Antwerp } \\
\text { [= Leiden] }\end{array}$ & $\begin{array}{l}\text { de Does, } \\
\text { widow F. }\end{array}$ & ${ }_{17} \mathrm{XX}$ & $\begin{array}{l}\text { No woodcut, } \\
\text { IHS vignette }\end{array}$ & Y & $?$ & $?$ \\
\hline Venlo & $\begin{array}{l}\text { Bontamps, } \\
\text { widow } \mathrm{H} \text {. }\end{array}$ & $18 \circ 5$ & $?$ & $?$ & $?$ & $?$ \\
\hline Venlo & $\begin{array}{l}\text { Bontamps, } \\
\text { widow } \mathrm{H} \text {. }\end{array}$ & 1817 & $\begin{array}{l}\text { JHWH, no } \\
\text { separate } \\
\text { bottom, Jn, } \\
\text { Mt, Lk, Mk }\end{array}$ & $\mathrm{N}$ & $\mathrm{N}$ & $\mathrm{Y}$ \\
\hline Geldern & $\begin{array}{l}\text { Schaffrath, } \\
\text { G. N. }\end{array}$ & 1820 & $?$ & $?$ & $?$ & $?$ \\
\hline Amsterdam & Lenfring, B. & 1828 & No woodcut & $\mathrm{N}$ & $\mathrm{N}$ & $\mathrm{N}$ \\
\hline Venlo & $\begin{array}{l}\text { Bontamps, } \\
\text { widow } \mathrm{H} \text {. }\end{array}$ & 1828 & No woodcut & $\mathrm{N}$ & $\mathrm{N}$ & $\mathrm{N}$ \\
\hline Turnhout & Brepols, P. & 1828 & $?$ & $?$ & $?$ & $?$ \\
\hline Turnhout & $\begin{array}{l}\text { Glénisson } \\
\text { and van } \\
\text { Genechten }\end{array}$ & 1828 & $?$ & $?$ & $?$ & $?$ \\
\hline Amsterdam & $\begin{array}{l}\text { J. L. F. } \\
\text { Eigendop }\end{array}$ & 1828 & $?$ & $?$ & $?$ & $?$ \\
\hline 's Bosch & van Gulick & 1828 & $?$ & $?$ & $?$ & $?$ \\
\hline
\end{tabular}




\begin{tabular}{|c|c|c|c|c|c|c|}
\hline $\begin{array}{l}\text { Poem for } \\
\text { school- } \\
\text { children }\end{array}$ & $\begin{array}{l}\text { Poem } \\
\text { Kinderen } \\
\text { sinnen }\end{array}$ & $\begin{array}{l}\text { Instructions } \\
\text { for prayer, } \\
\text { model } \\
\text { prayers }\end{array}$ & $\begin{array}{l}\text { 'Nota: } \\
\text { instruction } \\
\text { for if more } \\
\text { than } 24 \\
\text { Sundays after } \\
\text { Pentecost }\end{array}$ & $\begin{array}{l}\text { Tot den lezer: } \\
\text { instructions } \\
\text { for Sunday } \\
\text { observance }\end{array}$ & $\begin{array}{l}\text { Profiytelicke } \\
\text { Puncten } \\
\text { instructions } \\
\text { on godly } \\
\text { living }\end{array}$ & $\begin{array}{l}\text { Poem } \\
\text { Kinderen } \\
\text { sinnen and } \\
\text { poems for } \\
\text { parents } \\
\text { and } \\
\text { teachers }\end{array}$ \\
\hline $\mathrm{Y}$ & $\mathrm{N}$ & $\mathrm{Y}$ & $\mathrm{Y}$ & $\mathrm{Y}$ & $\mathrm{Y}$ & $\mathrm{Y}$ \\
\hline $\mathrm{N}$ & $\mathrm{N}$ & $\mathrm{N}$ & $\mathrm{Y}$ & $\mathrm{Y}$ & $\mathrm{Y}$ & $\begin{array}{l}\text { Only } \\
\text { poems for } \\
\text { parents } \\
\text { and } \\
\text { teachers }\end{array}$ \\
\hline$?$ & ? & $?$ & $?$ & $?$ & $?$ & $?$ \\
\hline$?$ & ? & $?$ & $?$ & $?$ & ? & $?$ \\
\hline $\mathrm{Y}$ & $\mathrm{N}$ & $\mathrm{Y}$ & Y & $\mathrm{Y}$ & $\mathrm{Y}$ & $\mathrm{Y}$ \\
\hline
\end{tabular}

?

?

$\mathrm{N}$

N

N

$\mathrm{N}$

$\begin{array}{lll}? & ? & ? \\ ? & ? & ?\end{array}$

\section{?}

$?$

$$
?
$$

$?$

$?$

$?$

$\mathrm{Y}$
$\mathrm{Y}$

$?$

$?$

?

?

$?$

? ?

$?$
$?$

$\mathrm{N}$
$\mathrm{N}$

$\begin{array}{ll}\mathrm{N} & \mathrm{N} \\ \mathrm{N} & \mathrm{N}\end{array}$


(cont.)

\begin{tabular}{llllll}
\hline Place & Publisher/ \\
printer & Year & $\begin{array}{l}\text { Description } \\
\text { of title page }\end{array}$ & $\begin{array}{l}\text { List of } \\
\text { moveable fixed }\end{array}$ & Preface & $\begin{array}{l}\text { Preface } \\
\text { publisher/ } \\
\text { holidays holidays }\end{array}$ \\
& & in & in & \\
& & Mechelen & Mechelen \\
& & diocese diocese
\end{tabular}

\begin{tabular}{|c|c|c|c|c|c|c|c|}
\hline Venlo & $\begin{array}{l}\text { Bontamps, } \\
\text { widow } \mathrm{H} .\end{array}$ & 1830 & $\begin{array}{l}\text { No woodcut, } \\
\text { vignette }\end{array}$ & $\mathrm{N}$ & $\mathrm{N}$ & $\mathrm{N}$ & $\mathrm{Y}$ \\
\hline Venlo & $\begin{array}{l}\text { Bontamps, } \\
\text { widow } \mathrm{H} \text {. }\end{array}$ & 1837 & $\begin{array}{l}\text { No woodcut, } \\
\text { vignette }\end{array}$ & $\mathrm{N}$ & $\mathrm{N}$ & $\mathrm{N}$ & $\mathrm{Y}$ \\
\hline Venlo & $\begin{array}{l}\text { Bontamps, } \\
\text { widow } \mathrm{H} \text {. }\end{array}$ & 1841 & No woodcut & $\mathrm{N}$ & $\mathrm{N}$ & $\mathrm{N}$ & $\mathrm{Y}$ \\
\hline Venlo & $\begin{array}{l}\text { Bontamps, } \\
\text { widow } \mathrm{H} \text {. }\end{array}$ & 1843 & $?$ & $?$ & $?$ & $?$ & ? \\
\hline Venlo & $\begin{array}{l}\text { Bontamps, } \\
\text { widow } \mathrm{H} \text {. }\end{array}$ & 1846 & $\begin{array}{l}\text { No woodcut, } \\
\text { vignette }\end{array}$ & $\mathrm{N}$ & $\mathrm{N}$ & $\mathrm{N}$ & $\mathrm{Y}$ \\
\hline Venlo & $\begin{array}{l}\text { Bontamps, } \\
\text { widow } \mathrm{H} \text {. }\end{array}$ & $185^{2}$ & $\begin{array}{l}\text { No woodcut, } \\
\text { vignette }\end{array}$ & $\mathrm{N}$ & $\mathrm{N}$ & $\mathrm{N}$ & $\mathrm{Y}$ \\
\hline Venlo & $\begin{array}{l}\text { Bontamps, } \\
\text { widow } \mathrm{H} \text {. }\end{array}$ & 1865 & $\begin{array}{l}\text { No woodcut, } \\
\text { vignette }\end{array}$ & $\mathrm{N}$ & $\mathrm{N}$ & $\mathrm{N}$ & $\mathrm{Y}$ \\
\hline Amsterdam & $\begin{array}{l}\text { Eigendop, } \\
\text { J. L. F. }\end{array}$ & 1865 & $?$ & $?$ & $?$ & $?$ & $?$ \\
\hline Amsterdam & $\begin{array}{l}\text { van Gulick, } \\
\text { W. }\end{array}$ & 1865 & $?$ & $?$ & $?$ & $?$ & ? \\
\hline Den Bosch & $\begin{array}{l}\text { van Gulick, } \\
\text { W. }\end{array}$ & 1865 & $?$ & $?$ & $?$ & ? & ? \\
\hline Amsterdam & Lenfring, B. & 1865 & $?$ & $?$ & $?$ & $?$ & ? \\
\hline Venlo & $\begin{array}{l}\text { Bontamps, } \\
\text { widow } \mathrm{H} \text {. }\end{array}$ & 1874 & $?$ & $?$ & $?$ & ? & ? \\
\hline Venlo & $\begin{array}{l}\text { Bontamps, } \\
\text { widow } \mathrm{H} \text {. }\end{array}$ & 1892 & $\begin{array}{l}\text { No woodcut, } \\
\text { vignette }\end{array}$ & $\mathrm{N}$ & $\mathrm{N}$ & $\mathrm{N}$ & $\mathrm{Y}$ \\
\hline
\end{tabular}




\begin{tabular}{|c|c|c|c|c|c|c|}
\hline $\begin{array}{l}\text { Poem for } \\
\text { school- } \\
\text { children }\end{array}$ & $\begin{array}{l}\text { Poem } \\
\text { Kinderen } \\
\text { sinnen }\end{array}$ & $\begin{array}{l}\text { Instructions } \\
\text { for prayer, } \\
\text { model } \\
\text { prayers }\end{array}$ & $\begin{array}{l}\text { 'Nota: } \\
\text { instruction } \\
\text { for if more } \\
\text { than } 24 \\
\text { Sundays after } \\
\text { Pentecost }\end{array}$ & $\begin{array}{l}\text { Tot den lezer: } \\
\text { instructions } \\
\text { for Sunday } \\
\text { observance }\end{array}$ & $\begin{array}{l}\text { Profiytelicke } \\
\text { Puncten } \\
\text { instructions } \\
\text { on godly } \\
\text { living }\end{array}$ & $\begin{array}{l}\text { Poem } \\
\text { Kinderen } \\
\text { sinnen and } \\
\text { poems for } \\
\text { parents } \\
\text { and } \\
\text { teachers }\end{array}$ \\
\hline $\mathrm{N}$ & $\mathrm{N}$ & $\mathrm{N}$ & $\mathrm{Y}$ & $\mathrm{N}$ & $\mathrm{N}$ & $\mathrm{N}$ \\
\hline $\mathrm{N}$ & $\mathrm{N}$ & $\mathrm{N}$ & $\mathrm{Y}$ & $\mathrm{N}$ & $\mathrm{N}$ & $\mathrm{N}$ \\
\hline $\mathrm{N}$ & $\mathrm{N}$ & $\mathrm{N}$ & $\mathrm{Y}$ & $\mathrm{N}$ & $\mathrm{N}$ & $\mathrm{N}$ \\
\hline$?$ & $?$ & $?$ & $?$ & $?$ & $?$ & $?$ \\
\hline $\mathrm{N}$ & $\mathrm{N}$ & $\mathrm{N}$ & $\mathrm{Y}$ & $\mathrm{N}$ & $\mathrm{N}$ & $\mathrm{N}$ \\
\hline $\mathrm{N}$ & $\mathrm{N}$ & $\mathrm{N}$ & $\mathrm{Y}$ & $\mathrm{N}$ & $\mathrm{N}$ & $\mathrm{N}$ \\
\hline $\mathrm{N}$ & $\mathrm{N}$ & $\mathrm{N}$ & $\mathrm{Y}$ & $\mathrm{N}$ & $\mathrm{N}$ & $\mathrm{N}$ \\
\hline$?$ & $?$ & $?$ & $?$ & $?$ & $?$ & $?$ \\
\hline$?$ & $?$ & $?$ & $?$ & $?$ & $?$ & $?$ \\
\hline$?$ & $?$ & $?$ & $?$ & $?$ & $?$ & $?$ \\
\hline$?$ & ? & $?$ & $?$ & $?$ & $?$ & $?$ \\
\hline$?$ & ? & $?$ & $?$ & $?$ & $?$ & $?$ \\
\hline $\mathrm{N}$ & $\mathrm{N}$ & $\mathrm{N}$ & $\mathrm{Y}$ & $\mathrm{N}$ & $\mathrm{N}$ & $\mathrm{N}$ \\
\hline
\end{tabular}

